\title{
Consequences of food energy excess and positive energy balance
}

\author{
Ricardo Uauy* and Erik Díaz \\ Institute of Nutrition and Food Technology (INTA), University of Chile, Macul 5540, Santiago, Chile
}

\begin{abstract}
This paper discusses possible consequences of energy excess throughout the life cycle. Firstly we consider the effects of foods on hunger, satiety and satiation. Also, the changes in food availability and consumption in relation to changes in social and economic determinants of energy excess. The relationship between physical activity and energy intake (EI) is also considered. Secondly we explore the definition of energy excess and the metabolic effects of macronutrients (mainly in relation to fuel partitioning oxidation/storage) on energy balance. The cellular and molecular regulation determined by specific genes involved in lipogenesis, fuel partitioning and/or in energy dissipation are explored. Thirdly, we examine the main consequences induced by energy excess and positive energy balance, starting with the alterations in glucose utilisation (insulin resistance) leading to type 2 diabetes and the linkage of energy excess with other non-communicable diseases (NCDs). Biological, social and psychological consequences during perinatal, childhood and adolescence periods are specifically analysed. Fourthly, the transition from energy deficit to excess, under the optic of a developing country is analysed with country examples drawn from Latin America. The possible role of supplementary food programmes in determining positive energy balance is discussed especially in relation to pre-school and school feeding programmes. Fifthly, we deal with the economic costs of energy excess and obesity related diseases. Finally, some areas where further research is needed are described; biological and genetic determinants of individual and population energy requirements, foods and food preparations as actually consumed, consumer education and research needs on social determinants of energy imbalances.
\end{abstract}

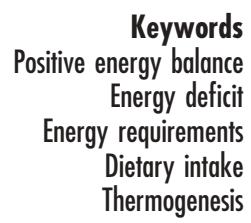

\section{Food energy excess}

\section{Conditioning factors of food intake}

The nutrient content of foods contributes to the taste, texture, viscosity, weight and bulk of the food, all are able to determine when and how much of food is consumed. The amount of food eaten at a particular time will depend on biological (metabolic mechanisms involved in nutrient processing, energy balance and appetite regulation) and environmental factors (nature of food supply, composition of foods, cultural and socio-economic conditions that determine dietary patterns). Eating in humans is episodic, each episode is controlled by mechanisms that regulate appetite, satiety, and satiation, which combined determine the size and frequency of eating episodes.

Food elicits distinct sensory inputs in addition to gastrointestinal and nutrient related signals, which modulate appetite through specific mechanisms involving different neurotransmitters including monoamines (noradrenaline, dopamine, serotonin, etc.), aminoacids (thryptophan, tyrosine, etc.), and neuropeptides (orexins, melanocortins, pancreatic polypeptides, hormone releasing factors, diverse gut brain peptides such as colecystokinin and neuropeptide Y, etc.). The autonomic nervous system and several circulating hormones (insulin, cortisol, growth hormone, leptin, etc.) are involved in the metabolic response to food intake. These signals, originating from food intake will generate neural as well as humoral outputs that would trigger the appropriate quantitative and qualitative adjustments not only in nutrient intake but also in energy and nutrient metabolism $^{1,2}$

Emotional and other psychogenic factors as well as the palatability of foods provide additional inputs that can exert strong, transient effects on the amount and type of food consumed from one meal to the next. In relation to satiety; defined as the effect of a test meal on the amount of food eaten in the following meal, carbohydrate exerts a more acute effect on satiety compared to fat. There is evidence that oro-sensory quality of dietary fat and carbohydrate $(\mathrm{CHO})$ may interact to influence the sensory stimulation to eat ${ }^{3}$. The effects of the combined ingestion of fat and sucrose has been tested, high fat-sweet snacks are associated to a significantly greater energy intake (EI). 
This effect is independent of the energy density of the snack implying that this combination promotes positive energy balance since more fat and energy are consumed, sensory cues related to satiety are clearly insufficient to preserve energy balance when sweet or salty fats are consumed ${ }^{4}$.

Manipulation of energy density of the diet affects appetite and energy balance. Different results are obtained depending on the macronutrient composition of the diet but the main variations in energy density are introduced by changes in the food content of fat, water and fibre. These same factors determine the actual level of EI in free-living subjects, it is difficult to single out which one is more relevant since they are covariant ${ }^{5}$. In relation to hunger and satiety, protein followed by $\mathrm{CHO}$ has more pronounced effects once palatability and energy density of the foods are the same. Changes in energy density by the incorporation of higher amounts of fat are not perceived by the subject, causing fat hyperphagia when covertly modified ${ }^{6-9}$. Other factors involved in appetite regulation include sight, smell, taste, and meal volume. Water and fibre content are the main determinant of meal volume ${ }^{10}$.

A typical western diet promotes excess EI and positive energy balance by a combination of these factors. Western populations with sufficient economic and market access to food consume on average $37-42 \%$ of their EI as fat. As the western diet is progressively imposed or is adopted by choice, in developing country populations obesity and type 2 diabetes increase. In some countries, these consequences of energy excess have reached epidemic proportions. Some have argued that the sensory appeal of fats and refined $\mathrm{CHO}$ and especially the combination rather than the vigorous marketing of these food products is a major facilitating factor in the rapid adoption of western-style foods ${ }^{3}$. The western diet when coupled with an increase in sedentarism contributes to the excess EI and positive energy balance. The rise in obesity found in countries that transit from their traditional diet to a more typical western diet is but a logic consequence. Social, cultural and economic factors that determine consumer behaviour should also be considered. For example, 'more food for less money' influences consumer preferences. This is reflected in progressively larger portion sizes and in marketing schemes such as 2 for 1, or bonus French fries. Also lack of time restricts the selection of foods such as legumes and other plant foods that require time to prepare. This favours the consumption of processed foods, commonly rich in fat, salt or sugar.

\section{Effects of non digestible carbohydrate}

Dietetic fibre represents all components from vegetable origins which are resistant to digestive enzymes in man. There is no agreement on the use of this term since there are multiple physiological effects depending on its chemical properties. The term fibre gathers many different food substances of varied chemical structure. Within them it can be distinguished: (1) structural carbohydrates which are part of the vegetable cell wall such as cellulose, hemicellulose and pectins, plus other non-carbohydrate components (lignin) and (2) non-structural carbohydrates, food additives such as gums, mucilage, algae polysaccharides and modified cellulose. The ability of fibre to absorb water, form colloids and its colonic fermentation produce an increase in faecal weight, a reduction in gut transit time and a reduction in nutrient absorption ${ }^{11}$.

In preventing weight excess, fibre can reduce energy density in the diet, induce satiation (reducing the amount of food consumed at that mealtime), make gastric emptying slower and reduce the amount of energy absorbed. Slower rate of $\mathrm{CHO}$ absorption produces less pronounced increases in glycaemia. Soluble fibres have hypocholesterolaemic effects by increasing excretion of biliary salts, altered formation of micelles, decreasing fat absorption, lowering cholesterol synthesis and enterohepatic recirculation.

\section{Type of CHO, glycaemic response, satiety, lipogenesis and} oxidation

The intensity of glycaemic stimuli will increase insulin secretion accordingly. This effect would promote $\mathrm{CHO}$ oxidation and fat storage. Counter-regulatory hormones will be released once the glycaemic effect has occurred to produce the reverse process. Glucagon regulates glucose production and epinephrine the release of fatty acids from body stores. Glycaemic response of healthy subjects to a dose of high glycaemic index (GI) food such as glucose and sucrose will reach the peak at around the 30 minutes following the test meal, dropping rapidly until basal levels or even lower than this by about 90-120 minutes. Responses obtained with low glycaemic index CHO such as fructose and maize starch, show a slower and flatter glycaemic curve which decreases slowly to reach the basal levels after 150 minutes. Few studies have related these changes with substrate utilisation, particularly with fat oxidation measured by indirect calorimetry. Results obtained show that highly glycaemic $\mathrm{CHO}$ produce a higher level of fat oxidation within a 6-hour period after the test meal in association with a higher plasma free-fatty acid level as compared to low glycaemic index CHO. This has been interpreted as an indication of greater stimulation of counter-regulatory hormones induced by the higher levels of glucose and insulin but unfortunately, just one of these studies measured epinephrine to ascertain that assumption $^{12,13}$. It is necessary to mention that in extrapolating these studies to real life situations it is necessary to consider that all of them supplied insufficient amount of energy compared with estimated requirements for the measurement period. This may partly explain why no differences are obtained under normal feeding conditions (Table 1).

A study conducted for a 24 hour period ${ }^{14}$ did not find an effect on $\mathrm{CHO}$ oxidation. A trend to higher $\mathrm{CHO}$ oxidation 


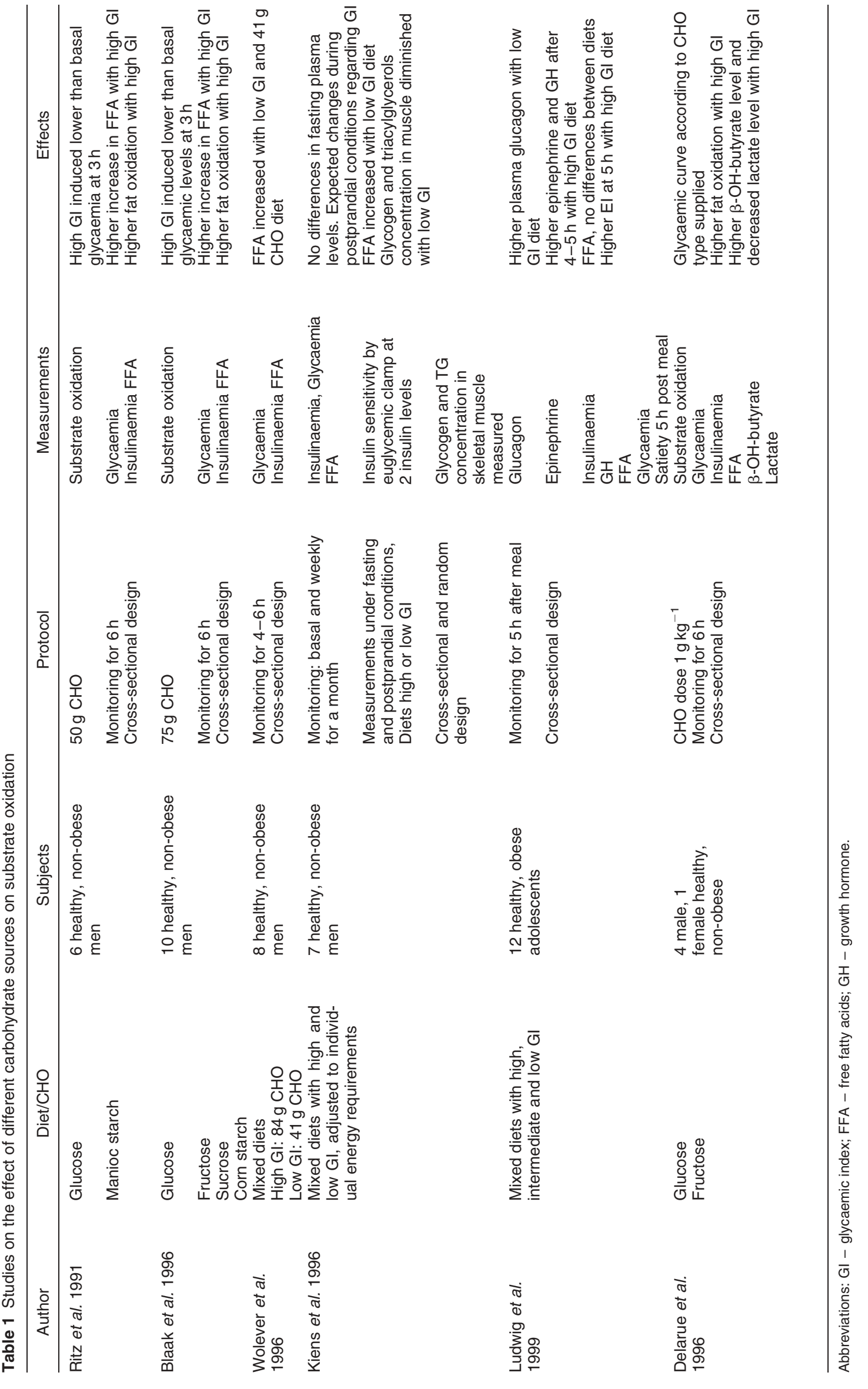


was found with the low versus high availability $\mathrm{CHO}$ during the daytime, but compensated with the opposite during the night. Fat balance was negative and $\mathrm{CHO}$ balance was positive in about the same amounts with the two treatments. Interpretation of these findings in terms of a glycaemic effect will be biased since the two diets were classified in terms of $\mathrm{CHO}$ availability only; its glycaemic response was not measured.

Another study conducted in eight lean and five obese women living in a whole-body indirect calorimetry chamber for 4 days in five separate occasions, were overfed by $50 \%$ over their energy requirements with either control diet, fat or $\mathrm{CHO}$. The latter from three different sources: glucose, fructose and sucrose. No significant differences were found in fat and CHO oxidation or energy and macronutrient balance ${ }^{15}$. The authors made clear that their results do not compromise the view that high fat diets are generally more fattening than are high $\mathrm{CHO}$ diets because of their increased energy density which promotes passive overconsumption, even when palatability is constant. Neither compromises the view that appetite control is less effective in response to high fat diets, particularly in certain vulnerable groups of population.

The avoidance of sucrose especially when combined with fat as a means to prevent excess EI is supported by a number of studies which suggest that this association promotes fat storage based on the hierarchy of substrate oxidation where $\mathrm{CHO}$ are readily oxidised in the presence of fat in the same meal ${ }^{16,17}$. Reduction of sucrose on its own is less justified, particularly if this recommendation is based on the potential induction of fat synthesis from $\mathrm{CHO}$ (de-novo lipogenesis). The latter has been demonstrated to be of marginal importance in triacylglycerols formation and storage in humans ${ }^{18,19}$.

In addition to the substrate oxidation effects induced by different CHOs, there are also effects on satiety. Studies performed by Ludwig et al. have shown that obese adolescents consuming test meals with similar macronutrient composition, fibre content and palatability, but with different GI (low, medium or high), experienced a higher EI after the high GI meal compared with the other two meals ${ }^{20}$. According to the authors, the rapid absorption of glucose was the conditioning factor in the excessive food intake in these obese subjects.

\section{Protein effects on appetite, satiety, metabolic response} Studies comparing the effects of high protein and high $\mathrm{CHO}$ meals on subsequent meal-time intake have shown some effects of protein in several studies ${ }^{21-23}$ but not in others $^{24-26}$. Less hunger in obese people was seen with a high protein versus a high $\mathrm{CHO}$ meal $^{22}$, significant reduction in food intake (26\%) at a subsequent meal and changes in motivational ratings ${ }^{21,23}$. In preschool children, two meals with a different supply of protein (12 versus $46 \mathrm{~g}$ ) and $\mathrm{CHO}$ (67 versus $13 \mathrm{~g}$ ) but the same energy content $(1.6 \mathrm{MJ})$ produced a significant difference of $328 \mathrm{~kJ}$
(78 kcal) in the same meal and a further reduction of $168 \mathrm{~kJ}$ in the following meal, accounting for a total of $18 \%$ reduction in EI of $496 \mathrm{~kJ}$ ( $119 \mathrm{kcal})$ on average $\mathrm{e}^{27}$. It was found that a high protein meal has a greater effect on satiation (immediate intake) and satiety (next meal effect) in preschool children. It has been shown that high protein meals have the capacity to increase short-term satiety, and follow a dose-dependent relationship ${ }^{28}$. These effects may be explained by the effect of specific aminoacids to stimulate the release of neuropeptide $\mathrm{Y}$ and cholecystokinine, both implicated in the satiety response. It is also possible that increased aminoacid oxidation in the gut and liver induces satiety and satiation responses via afferent vagal fibres. These findings should be considered in addition to the lower palatability of protein compared to a $\mathrm{CHO}$ rich diet. These results suggest that a high protein diet could be beneficial on obesity prevention.

\section{Food intake and physical exercise}

The level of physical activity can influence food intake through a reduction in appetite and fat intake ${ }^{29}$. Exercise has been reported to produce a reduction in food intake, which is not fully compensated in the following days. King et $a l .{ }^{30}$ have shown that subjective feelings of hunger were significantly suppressed immediately and after exercise. Intense exercise delayed the time to start eating although it had no effect on the amount of food consumed ${ }^{31}$. The opposite seems to hold true, being likely that sedentarism could somehow stimulate food consumption.

\section{Changes in dietary intake with social, economic and cultural determinants}

Trends in food expenditures and consumption indicate that dietary changes are accelerating throughout the emerging economies and developing nations. The shift toward a high fat energy-dense diet is most rapid and runs in parallel with the emergence of obesity as a public health problem. There is an urgent need for these nations to consider ways of preserving positive aspects of the traditional diet and to promote healthy lifestyles. The Latin America region is a good example of this situation, and particularly interesting is the case of Chile, where changes have occurred at an impressive speed.

The Latin American region has experienced a major demographic, epidemiological and nutritional transition over the past three decades. An improvement in the overall socio-economic situation and human development indicators are occurring in most countries in the region. Urbanisation trends and economic growth have deeply changed the Latin American lifestyle over the past 20 years. This has influenced the epidemiological profile and the associated nutritional problems ${ }^{32}$. The speed of these changes varies as a function of demographic changes and the industrialisation process. Yet, for most countries, the progressive significance of diet related chronic diseases are a common consequence ${ }^{33}$. 
For example, Chile's biomedical indicators in the $60 \mathrm{~s}$ matched those of most Latin American countries. That is high maternal and infant mortality rates (IMR), high prevalence of infectious diseases and undernutrition. In the late 90s, the Chilean nutrition and health situation was completely different. The present scenario is an IMR of 10 per 1000 live births ${ }^{34}$, while in the region it is $35.7^{35}$. Moreover, during this period non-communicable chronic diseases have increased from 54\% of all deaths in 1970 to $75 \%$ in $1998^{36}$. The main causes of death are now cardiovascular disease, neoplasm and external causes (including accidents). Concomitantly, a rapid increase in risk factors for chronic diseases has been noted in several national surveys ${ }^{37-41}$. A reversal of malnutrition, with the virtual eradication of protein energy undernutrition and an increase in obesity, has also occurred in this decade ${ }^{42}$.

As happens in other regions of the world, dietary components change as income increases, particularly overall EI and total fat, especially from saturated fat. On the contrary, intake of cereals, legumes and other fibre rich foods such as vegetables and fruits, remain the same or in decline.

The relative contribution of fat to EI as well as the type of fat consumed is closely related to the stage of the epidemiological transition. Countries with the highest intake of saturated fat also have higher prevalence of cardiovascular diseases and diet related chronic diseases. In the Latin America region, Argentina and Uruguay have the highest fat intake. Over the past years, Chile has increased the consumption of fat at a rapid rate reaching the same level of intake observed in Mexico. Nicaragua, presently at the early stages of epidemiological transition has low total fat intake as well as animal fat intake. Chile in 1975 had a human fat intake of $13.9 \mathrm{~kg} /$ person per year which increased to $16.7 \mathrm{~kg} /$ person per year in 1995 . Both saturated and polyunsaturated fat intake has increased ${ }^{43}$.

Although the mean fat intake is around $28 \%$ of total EI (much less than many industrialised countries), the prevalence of obesity is rising rapidly ${ }^{44,45}$. The increase in the amount of fat followed by a sedentary lifestyle are the most likely explanations for the fast rise in obesity.

\section{Positive energy balance}

\section{Macronutrients' effects on energy balance}

Man obtains metabolic energy from a variety of sources; carbohydrates, fats, proteins and alcohol all serve as fuels with a specific energy value depending on the chemical nature of the macronutrient. Humans in fact can obtain their energy from a mix of these sources over different ecological settings, allowing the species to span the globe utilising the various foods available. Thus the availability and not the type of food energy is undoubtedly the crucial limiting factor for human population growth and density. Human evolution up until the modern era was characterised by a closed coupling between EI and physical work.
Even after the advent of agriculture most humans had to physically work for sustenance. Very few individuals within a society were able to eat out of the work of others. It is only after the industrial revolution and development of market economies that food production allows for a third or more of the human race to accumulate energy excess in the form of body fat stores. Human evolution occurred with alternating periods of energy deficit (famines) and food availability. This process repeated through thousands of generations is a powerful evolutionary force inducing multiple adaptations in our physiology with the aim to optimise energy absorption, fat storage and minimising losses ${ }^{46}$. Biologically, we are ill prepared to handle energy excess, thus unless we readdress the energy balance equation by increasing expenditure we will be faced with the health and social consequences of positive energy balance and obesity. The amount of energy per unit of mass or volume for liquid foods is known as energy density. Foods with higher energy density are generally more palatable, since they have a higher fat and sugar content. The metabolic effects of energy excess are associated with the balance established between EI and energy expended (EE). This calculation is known as the energy balance $(\mathrm{EB}=\mathrm{EI}-$ EE). Presently, energy balance study methodology permits the derivation of energy balance for each macronutrient, indicating the fate of energy accumulated from $\mathrm{CHO}$, fat or protein balance. Thus the fate of excess energy over requirements for a specific time and a given macronutrient consumed can be calculated. In this section we will discuss the effects of excess energy both from mixed sources and from the intake of a specific macronutrient. We will address the biological consequences at various levels, cells, organ, and whole body. Pathological effects will be considered in the next section.

\section{Fatty acids}

Fat is an important determinant of energy excess and positive energy balance. In addition to the total amount of fat, the degree of saturation (saturated, MUFA or PUFA) and the presence of double bonds in positions n-9, n-6, $\mathrm{n}-3$, and their respective ratios are significant in terms of energy balance and health effects. Differences in chemical structure of lipids have a direct effect on lipoprotein metabolism, eicosanoid mediated events, fuel partitioning to oxidation or storage, insulin resistance (IR) and other metabolic effects of excess fat energy. The greater the number of carbons, the lower the oxidation rate. On the contrary, unsaturated fatty acids are more easily oxidised both in animals and humans ${ }^{47-50}$. Leyton et al. ${ }^{47}$ measured the oxidation of $14 \mathrm{C}$-labelled fatty acids in rats. Within saturates, lauric and miristic acids were the most readily oxidised (64\% and 40\%, respectively). Among the unsaturates $\alpha$-linolenic acid (18:3n-3) exhibited the highest rate of oxidation (65\%), followed by oleic and linoleic acids (57\% and 48\%, respectively). Fatty acids also 
have differential effects on specific enzymes responsible for lipid transport and oxidative metabolism. Thus, $\alpha$-linolenic acid has the greater induction effect on carnitine acyl-transferase (CAT-I, rate limiting step for fatty acid oxidation in the mitochondria). In contrast, saturated fatty acids stimulate lipogenic enzymes such as acetyl coenzyme-A carboxilase, fatty acid synthase, among others ${ }^{51-53}$

\section{Carbohydrates}

It is presently evident that the energy value for specific macronutrients known as Atwater factors needs to be updated. Although the combustion energy value of food components has not changed, food processing and technology has changed absorption and energy availability. We now have a greater knowledge of how food processing modifies availability and have a greater variety of carbohydrates in foods. CHO energy utilisation of a given food combination and its glycaemic-insulinaemic response will depend on its degree of polymerisation (mono, di, oligo and polysaccharides), amilose and amilopectin content, colonic fermentation and amount of dietary fibre and resistant $\operatorname{starch}^{11}$. From a physiological standpoint, the metabolic effects of excess CHO energy are related not only to its own metabolism but also to a variable effect on fat storage. This effect will depend on the rise on glycaemia and insulinaemia, which in turn would promote oxidation of $\mathrm{CHO}$ and an increase in fat storage. Apparently the release of counter-regulatory hormones once glycaemia returns to basal levels is directly dependent on the strength of the glycaemic stimuli. Thus, a high glycaemic meal will produce a greater rebound of those hormones, stimulating their secretion and promoting lipolitic effects. Given the importance of this finding on establishing dietary recommendations, this issue should be studied further. Fat balance over a given period of time will depend not only on fat intake but also on how $\mathrm{CHO}$ intake affects lipolysis and the partitioning of fat energy into lipid storage or oxidation.

These considerations are usually made for a particular food but rarely for the combined effects of several foods eaten in a meal. The given macronutrient combination will induce metabolic responses which are not predicted based on the added effect of each individual food item. The fate of energy excess will depend on overall energy balance and the hormonal responses, which regulate the partitioning of macronutrients into the oxidative pathway or lipid storage. As described in this section both factors may be affected by type of $\mathrm{CHO}$ and fat consumed.

\section{Alcohol}

There is no storage capacity for alcohol derived energy. Ethanol is oxidised completely in the period immediately following its ingestion. Its quick and efficient oxidation dominates oxidative pathways and suppresses the rates at which the other fuels are oxidised. Thus, the effect of alcohol energy on fat storage is indirect. It acts by sparing $\mathrm{CHO}$ and fat oxidation, making the latter more available for storage. The adverse effects of excess ethanol consumption are related to the liver damage it induces. The first step of this process is an accumulation of fat within the hepatocytes, termed steatosis.

From the above information, it can be summarised that the effects of macronutrients on energy balance go beyond their energy value. The effects on fuel partitioning can be summarised in the following terms. If energy supply exceeds needs, energy has to be deposited particularly in the postprandial period. Minute by minute energy balance after a meal will certainly be positive for several hours in sedentary persons. Thus, the amount of food energy consumed will surely exceed accumulated energy needs over the same period. The type of fatty acids consumed will have a differential effect on disposal by oxidation depending on the length, degree of unsaturation and position of double bonds. The amount of fat eaten will most certainly influence energy density of meals and the likelihood of a positive energy balance. The type of $\mathrm{CHO}$ combination consumed at each meal will determine a specific glycaemic and insulinaemic response affecting not only $\mathrm{CHO}$ oxidation but also fat storage. Substrate oxidation will proceed according to a hierarchy where carbohydrates are preferentially oxidised, followed by protein and finally fat. Under usual conditions, $\mathrm{CHO}$ are rarely converted to fat, and if de novo lipogenesis occurs, it is quantitatively small relative to storage of preformed fatty acids. Only if $\mathrm{CHO}$ overfeeding is maintained over time lipogenesis may be induced to a greater extent.

\section{Overfeeding studies}

The effects of energy excess leading to positive energy balance and obesity are difficult to study, particularly during the dynamic phase of weight gain. Most research contrasts obese with lean persons, but for the obese person, excess fat storage is already present. Thus, we cannot evaluate how they become obese in the first place. Overfeeding (OF) studies under controlled conditions are the only way to look dynamically at the metabolic changes induced by energy excess and the fate of accumulated energy. Over the past century there have been multiple studies to evaluate this question. They vary in duration, amount and type of energy excess provided and overall design. In order to systematically review the available studies we defined the following selection criteria: (1) Careful assessment of energy balance, measurements of intake/metabolisable energy and energy expenditure with its components; basal metabolic rate/resting metabolic rate $(\mathrm{BMR} / \mathrm{RMR})$ and activity plus thermogenesis. Ideally, measurements of total energy expenditure (TEE) under free-living conditions using doubly labelled water (DLW); (2) measurement of energy stored as body fat at the beginning and end of the overfeeding period using accurate and precise methods; (3) a baseline period to 
estimate individual energy requirements; (4) a clear definition of the amount and type of energy excess provided to each subject based on individual requirements; (5) measurements of energy balance and storage performed at the beginning and throughout the overfeeding period; and (6) sufficient duration of the overfeeding period to permit the evaluation of significant changes in body weight and composition. We did not intend to conduct a formal meta-analysis of the studies therefore we did not place a restriction on the number of subjects studied or on specifications of randomisation procedures when appropriate. The past 25 years were evaluated and found 17 overfeeding studies but only eight of them met the specified selection criteria relatively well. The main problem found in the excluded studies was that the amount of energy excess supplied was fixed for all subjects, representing a variable difference in EI rather than a defined percent of excess in relation to a subject's energy needs ${ }^{54-56}$. The main aspects to be considered in the interpretation of these studies are the following:

- The calculation of actual energy excess is undoubtedly the key variable; unfortunately the balance between energy expenditure and EI combines the measurement errors in both variables. For example, intake assessment may have an intrinsic error related to the weighing of food ingredients and energy value of foods but also, compliance with prescribed EI may vary independent of investigator's efforts in trying to control it. Moreover, food intake is always subject to overestimation due to incomplete consumption or inadvertent losses. On the other hand, estimates of energy expenditure, even when obtained by DLW, have an inherent error depending on the time frame of the study period. These may add up to a significant proportion of the desired energy excess affecting the balance and introduce systematic biases.

- Accuracy in the estimated energy output during the study period will depend on constancy of TEE. The minimum period for DLW estimates of TEE is 10-14 days, usually performed at the end of the OF period. This implies that variations in TEE that may have occurred earlier in the study will go undetected.

- Changes in body weight and composition require at least 2 weeks to show significant variations. During this time, changes in body composition compartments are not equally affected. Therefore, the difference between expected amount of weight gain based on energy excess and the observed changes usually differ. The expected change in weight is based on the assumption of a fixed composition of accumulated energy and a constant rate of storage estimated from the mean changes in body energy stores.

- As described above, another source of error relates to the estimates of body composition and the calculations of energy costs of tissue deposited based on published energy equivalencies of lean and fatty tissue. The latter may not account for the smaller amount of fat accumulated at the beginning of the study period. Body composition, on the other hand, varies depending on the method used. A detailed study by Jebb et al. ${ }^{57}$ clearly demonstrated in subjects confined to a metabolic chamber during 14 days, that estimates of changes in body composition by hydrodensitometry, total body water, potassium- 40 varied immensely. For one of the subjects, the variation in fat storage by hydrodensitometry was half of the amount estimated by a three compartment model (1.2 versus $2.2 \mathrm{~kg}$, respectively).

- The type and proportion of macronutrients fed either as $\mathrm{CHO}$ or fat are important determinants of the amount of fat stored, particularly in the early stages of overfeeding ${ }^{58}$. This has not been considered, except in the more recent studies.

- The usual explanation for the unaccounted energy after subtracting total energy spent and energy stored from the amount of EI is termed 'energy dissipation, luxuskonsumption or adaptive thermogenesis'. This process is hypothetically related to the existence of futile cycles or respiratory chain uncoupling in response to overfeeding. The method chosen by many to assess this phenomenon has been indirect calorimetry. Unfortunately this method is unable to separate thermogenesis from physical activity components within TEE since they are calculated by difference [TEE - (BMR + TEF)]. Controlled studies using whole body calorimetry chambers have concluded that the thermogenic component is insignificant after the thermic effect of food (TEF) is taken into account ${ }^{17,57,59}$. Nevertheless, individual differences in thermogenesis are highly variable. This is particularly true in response to OF with low protein diets as found by Miller in $1967^{60}$ and revisited recently ${ }^{55}$. This finding has been suggested as a way to magnify possible adaptive thermogenesis in humans. Neither is taken into account the recent evidence on molecular mechanisms regulating mitochondrial and peroxisomal fuel oxidation. It is suggested that indeed the oxidative process may be uncoupled to varying degrees by specific uncoupling proteins (UCPs) that may respond to hormonal and substrate related signals. In addition specific genotypes may be more or less able to mount a thermogenic response after overfeeding. Thus despite insufficient evidence from human studies, energy dissipation may still be at the heart of the matter in understanding the disposition of positive energy balance when excess energy is consumed.

\section{Genes and positive energy balance}

Studies conducted on twins and their relatives have shown that $50-70 \%$ of body mass index (BMI) variation could be attributable to genetic differences ${ }^{61}$. Some rare forms of 


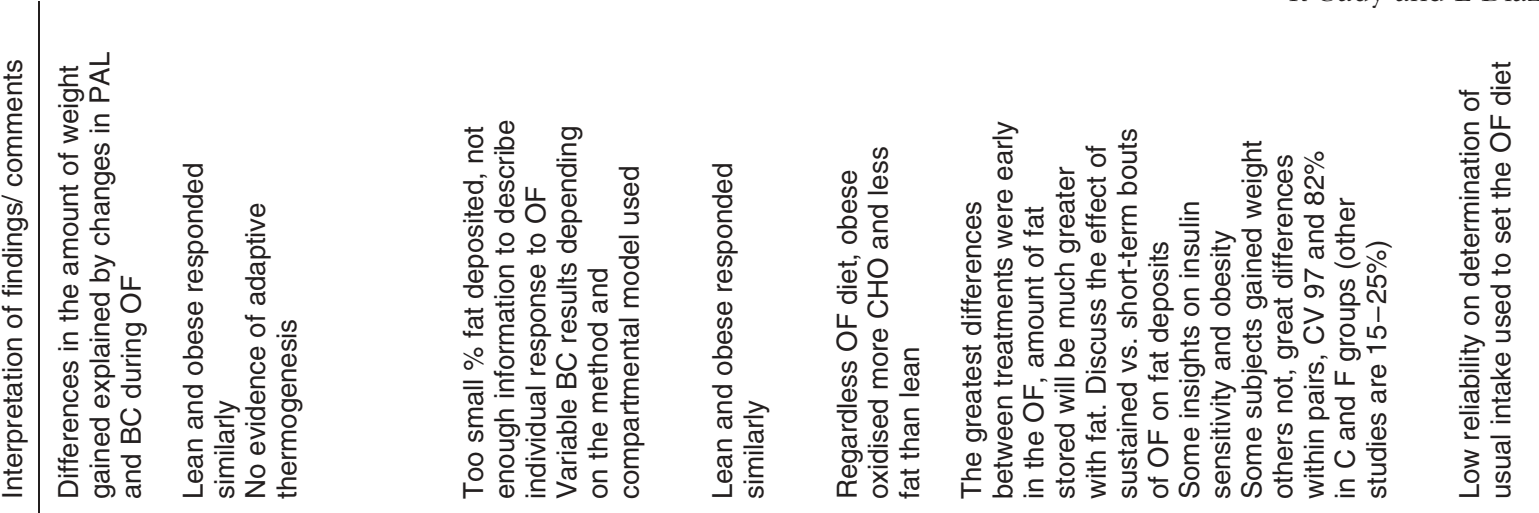

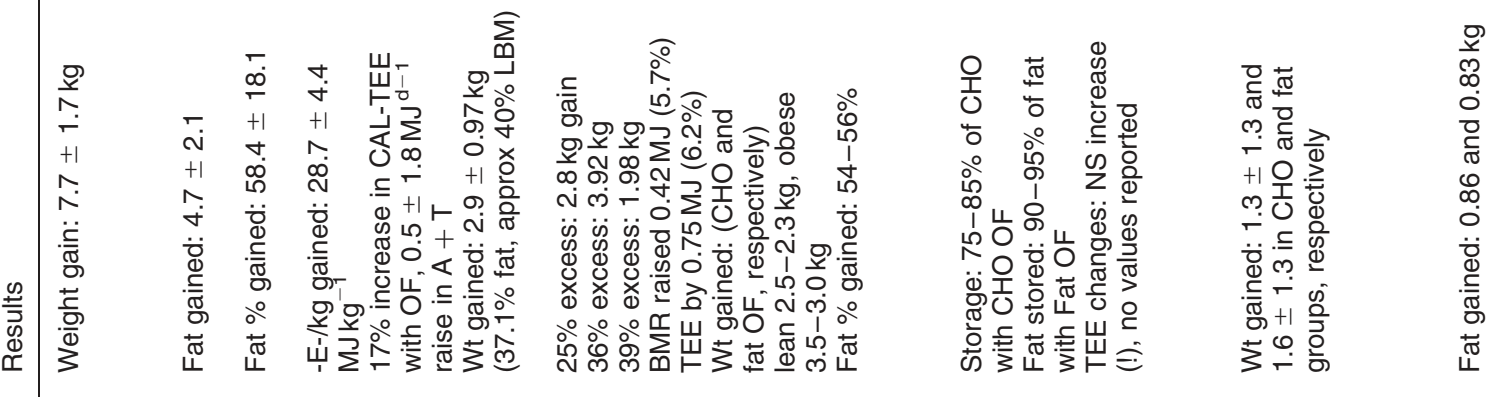

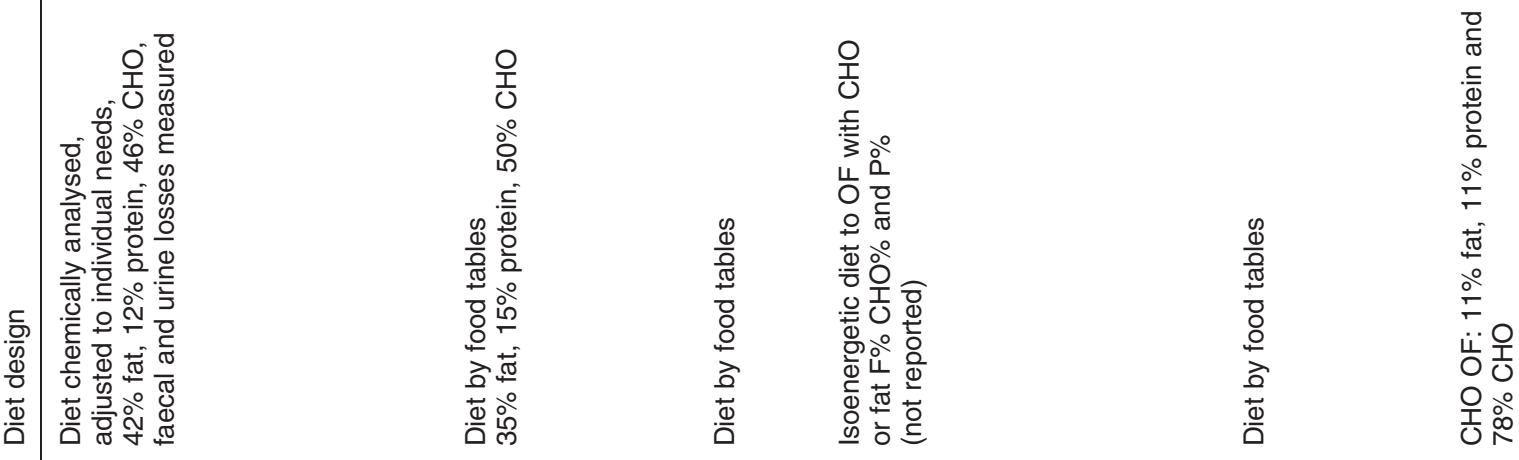




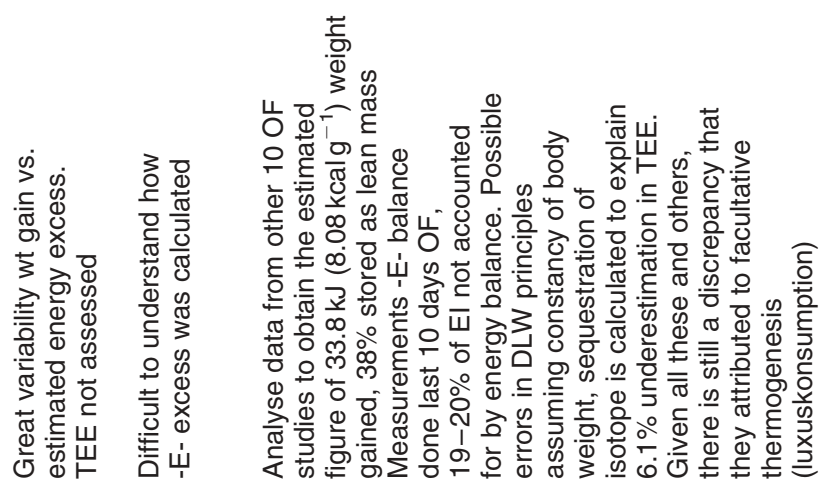

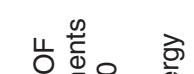

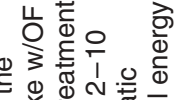

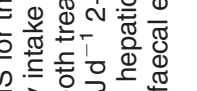

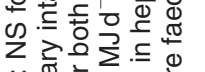

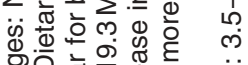

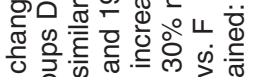

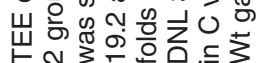

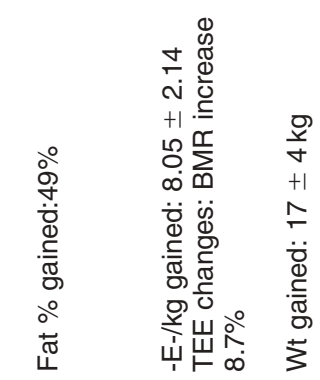

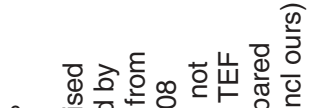

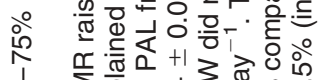

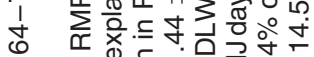

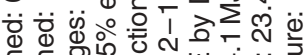

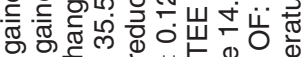
- 000

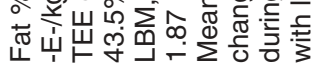
a.

\begin{tabular}{|c|}
\hline 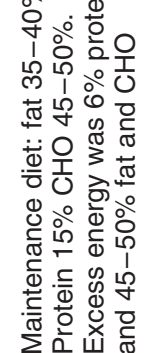 \\
\hline
\end{tabular}

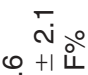

लं

+l 건

少

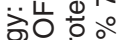

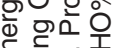
든.

응

政

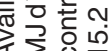




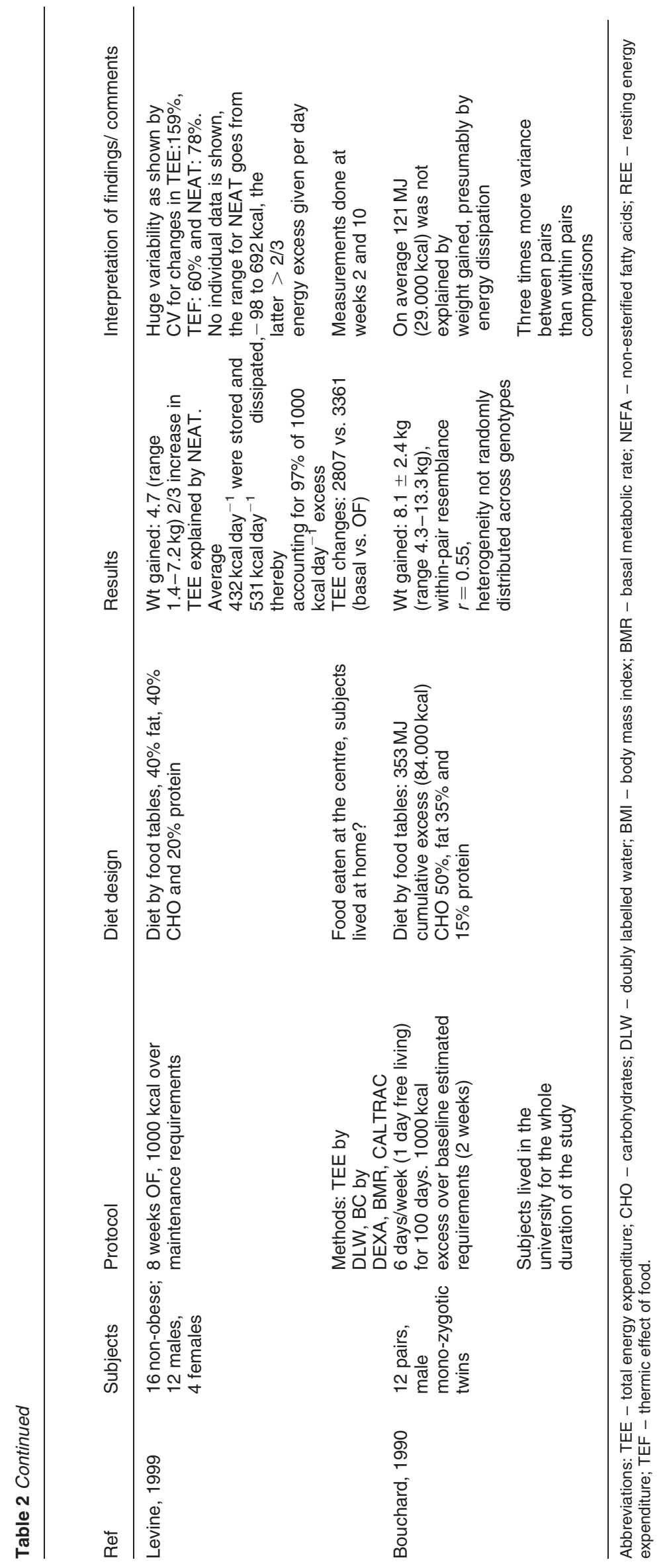


monogenic mutations (major genes) have been described in humans such as leptin, leptin receptor, pro-opiomelanocortin, prohormone convertase-I and melanocortin receptor, all of which are associated with juvenile obesity. A number of other (minor genes) are associated with excessive weight in some but not all subjects having the genetic polymorphism. In this regard, some of them are responsible for energy dissipating mechanisms therefore preventing the accumulation of body fat such as the $\beta 3$ adrenergic receptor and UCPs. Others can induce adipocyte differentiation and energy storage as the peroxisome proliferator-activated receptors (PPARs), stimulate lipolysis and IR as tumour necrosis factor alpha $(\mathrm{TNF}-\alpha)$.

\section{$\beta$-adrenergic receptors}

Catecholamines stimulate lipolysis through the $\beta$-adrenergic receptors and inhibit lipolysis through $\alpha$-adrenergic receptors. The $\beta 2$-adrenergic receptors are expressed in several tissues including lung and adipose tissues. It plays several roles in the regulation of glycogen breakdown and stimulation of lipid mobilisation. The $\beta 2$ adrenoceptor is the dominating lipolytic adrenoceptor under normal conditions and is down regulated in subcutaneous adipose tissue of obese subjects. The latter is an important underlying mechanism for the frequently observed lipolytic catecholamine resistance in human obesity. The $\beta 3$-adrenergic receptor in humans was thought to be less relevant since it is expressed in brown adipose tissue, although it has been found in visceral adipose tissue ${ }^{62}$. Subsequently, it gained importance when it was demonstrated that catecholamine-induced lipolysis was increased in visceral fat of abdominal obesity due to increased $\beta 3$ adrenergic receptor function ${ }^{63}$. The $\beta 3$-adrenergic receptor thereby became a prime candidate gene for abdominal obesity. Its prevalence differs between populations, with an allele frequency of 10\% in Finns and 30\% in Japanese ${ }^{64}$. Genetic polymorphisms Gln27Glu in the $\beta 2$ adrenoceptor gene and Trp64Arg in the $\beta 3$ adrenoceptor gene have been associated with obesity ${ }^{65,66}$. However, epidemiological studies have shown discordant results regarding the impact of such polymorphisms on the predisposition to overweight in different populations ${ }^{67-69}$.

\section{UCPS}

Thermogenesis in rodents is largely explained by activity of the mitochondrial UCPs. These proteins are protonchannel proteins on the inner mitochondrial membrane and uncouple oxidative phosphorylation by converting the electro-chemical potential of the mitochondria into heat instead of ATP. There are three forms of UCPs described; UCP1 is mostly expressed in brown adipose tissue, UCP2 in most tissues including white adipose tissue, and UCP3 is strongly expressed in skeletal muscle. In humans, a polymorphism in the promoter region of the UCP1 gene on chromosome 4 is associated with weight gain, and is further accentuated if the patient has the Trp64Arg mutation in the $\beta 3$-adrenergic receptor gene ${ }^{65}$. So far no mutations in the coding sequences or promoter regions of UCP2 and UCP3 have been associated with human obesity and it is not known for sure whether they are real $\mathrm{UCPs}^{70,71}$.

\section{PPARS}

The PPARs are a family of nuclear receptors which have received considerable attention due to their major role in the regulation of lipid and glucose metabolism and adipocyte differentiation ${ }^{72}$. PPAR isoforms $\alpha, \beta$, and $\gamma$ are encoded by different genes and can be distinguished based on their metabolic effects, differential tissue specific expression and responsiveness to pharmacological agents ${ }^{73}$. PPAR- $\alpha$ is involved predominantly in fatty acid metabolism in liver, but is also expressed in other tissues such as kidney, heart, skeletal muscle and brown adipose tissue $^{74}$. The expression of PPAR- $\gamma$ is predominantly observed in adipose tissue where it normally acts by suppressing adipocyte differentiation ${ }^{75}$. There are two PPAR $\gamma$ isoforms derived from the same gene by alternative promoter usage and splicing. Specific mutations for PPAR $\gamma-2$ are associated with enhanced adipocyte differentiation but have a negligible effect on insulin sensitivity. This genetic condition, associated with massive obesity but minimal IR, has recently been identified in humans ${ }^{76}$. The PPAR family of nuclear receptors has received considerable attention due to its major role in the regulation of lipid and glucose metabolism and adipocyte differentiation.

The most abundant of PPAR isoforms in adipose tissue is PPAR- $\boldsymbol{\gamma}$. It controls the expression of a large number of genes involved in adipocyte differentiation, lipid storage and insulin sensitivity. PPAR- $\gamma$ is bound and activated by fatty acids derivatives and prostaglandin J2. In addition thiazolinediones, non-steroidal anti-inflammatory drugs are synthetic ligands and agonist of this receptor. Activated PPARs heterodimerise with another nuclear receptor, retinoid $\mathrm{X}$ receptor (RXR), and alters the transcription of numerous target genes after binding to specific response elements (PPRE) in the DNA. In vivo, adipocyte differentiation requires the synergistic action of PPAR- $\gamma$, RXR and two enhancer binding proteins. The enhanced adipocyte differentiation, which ensues from PPAR- $\gamma$ activation, triggers the expression of specific genes involved in lipid transport, metabolism and storage. For example, adipocyte binding protein (aP2), phosphoenol piruvate carboxykinase (PPECK) key enzyme for the fuel oxidation, acyl CoA synthase relevant to fat synthesis; fatty acid translocase, fatty acid transport protein-1 and lipoprotein lipase (LPL) associated to transport are regulated by PPARs. In addition to these, two cytokines produced by the adipocyte; tumour necrosis factor alpha $(\mathrm{TNF}-\alpha)$ and leptin, also appear to participate in the differentiation process. PPAR- $\gamma$ is thought to modulate the 
expression of adipocyte derived signals affecting insulin sensitivity in skeletal muscle such as TNF- $\alpha$.

Adipose tissue is required for glucose homeostasis in response to insulin. Indeed, human subjects ${ }^{77}$ and transgenic animals with lipoatrophy ${ }^{78}$ are very insulin resistant. This indicates, that storage of energy reserves in the adipocytes favours insulin sensitivity, and that the important adipogenic activity of PPAR- $\gamma$ contributes to the improved insulin sensitivity after thiazolinediones (TZD) treatment. This is due to a specific TZD induced PPAR $\gamma$ mediated increase in lipid and fatty acid clearance by adipose tissue, without a concomitant increase in fatty acid delivery to the muscle ${ }^{79}$. Fatty acids, by this mechanism, remain in adipose tissue, decreasing systemic availability of free fatty acids (FFA) and improving muscle insulin sensitivity. It is also suggested that PPAR $\gamma$ could also affect insulin signalling more directly through the regulation of genes directly involved in glucose homeostasis such as Glut 4 and others ${ }^{80}$.

Recently, mutations in PPAR- $\gamma$ gene have been described. A rare Pro115Gln mutation in the amino terminal ligandindependent activation domain of PPAR $\gamma$ was found in four very obese subjects ${ }^{76}$. This mutation, which results in a more active PPAR $\gamma$, led to increased differentiation capacity in vitro. Other much more common Pro12Ala substitution in the PPAR $\gamma 2$-specific exon B has been described ${ }^{81}$. The PPAR- $\gamma 2$ allele whose frequency ranges from 0.12 among Caucasians to 0.02 in Japanese Americans ${ }^{82,83}$ was associated with a lower BMI, improved insulin sensitivity, and higher plasma HDL cholesterol levels ${ }^{82}$. There have been other reports which did not find association between the Pro12Ala substitution and insulin sensitivity ${ }^{84,85}$ but found it in morbid obesity, suggesting that it may be different in lean and obese conditions. The findings from a Danish study in males ${ }^{86}$ agrees with this since they observed that Ala allele was associated with lower BMI in lean subjects and with higher BMI in obese individuals.

\section{Consequences of positive energy balance}

\section{Associated bealth problems to excess body weight and obesity}

The non-fatal but debilitating health problems associated with chronic energy excess and obesity include respiratory difficulties, chronic muscle-skeletal problems, skin problems and infertility. The more life-threatening, chronic health problems fall into four main areas: (1) conditions associated with IR, namely non-insulin dependent diabetes mellitus (NIDDM); (2) cardiovascular problems including hypertension, stroke and coronary heart disease; (3) certain types of cancers, mainly the hormonally-related and large bowel cancers; and (4) gallbladder disease.

\section{IR and NIDDM}

One of the most important complications induced by a sustained positive energy balance is the metabolic syndrome or syndrome $\mathrm{X}^{87}$. This is a cluster of symptoms including IR, dyslipidaemia and hypertension. IR seems to be the central feature and the first step in the chain of events of which the progression is not well understood yet. IR is a continuum, which progresses with age and degree of obesity; the manifestations include metabolic alterations in glucose and lipoprotein metabolism to clinical diabetes and heart disease. Recent reports suggest that as obesity increases in children and adolescents type 2 diabetes is no longer an exclusively adult disease, severe IR and hyperglycaemia are now being observed in adolescents $^{88}$.

Insulin has metabolic effects in the liver, muscle and adipose tissues while resistance to its effects may be tissue specific. Insulin sensitivity is impaired first in adipose tissue, producing the increased release of fatty acids to the plasma ${ }^{89}$. This is considered as the main factor associated with the metabolic alterations observed in obese persons. The origin of IR in obesity is unknown, earlier explanations postulated that differences in fatty acid composition of plasma membrane influenced insulin sensitivity ${ }^{90,91}$. Presently, the prevailing idea is that the amount of fat stored in the cytosol, particularly at the skeletal muscle impairs glucose uptake through complex molecular mechanisms ${ }^{90,92}$. In this regard, the amount and type of metabolisable fat (saturated versus PUFA) are highly relevant. Moreover, the expansion of adipose tissue either by adipocyte hypertrophy or hyperplasia or both, may induce an increase in the production and release of specific cytokines, particularly TNF- $\alpha$ which has been found to be elevated in the obese. Adipocyte and miocyte are the main sites where TNF- $\alpha$ exerts its autocrine, paracrine and possibly an endocrine effect, inhibiting the action of insulin cascade, impairing glucose uptake and oxidation $^{93,94}$.

The true prevalence of IR under conditions of energy excess and obesity is not well established since its frequency has been usually estimated using fasting serum insulin and glucose. This is a rough index of IR since hyperinsulinaemia is not always accompanied by a cellular glucose uptake reduction. Studies using euglycaemic hyperinsulinaemic clamp have found that $26 \%$ of normotense obese are insulin resistant ${ }^{95}$. There is no uniform quantitative definition of IR neither a cut-off point for abnormality. A major limitation is the lack of a suitable method to measure IR reliably in epidemiological studies. Using the euglycaemic hyperinsulinaemic clamp in normal subjects is probably the best method to assess IR. The mean rate of glucose infusion during the clamp ( $M$ value) for young normal weight subjects with normal glucose tolerance is of the order of $7-12 \mathrm{mg} \mathrm{kg}^{-1}$ body weight/minute. This compares to the values of 3$4 \mathrm{mg} \mathrm{kg}^{-1}$ body weight/minute in the extensively studied Pima Indians in whom IR is a common finding ${ }^{96}$.

IR, considered to antedate the onset of NIDDM, is not necessarily associated with obesity. However, this is 
usually assumed based on the frequently observed hyperinsulinaemia in obese subjects. The decrease in beta cell function related to IR and hyperinsulinaemia is not fully understood. The most likely possibility is a combination of one or more of the following factors: single or polygenic defects that affect insulin action or glucose disposal, beta cell damage from glucose toxicity, amylin deposition, and epigenetic factors such as maternal/foetal/infant malnutrition which may induce metabolic programming, obesity and sedentary lifestyles ${ }^{97,98}$. Hyperinsulinaemia has been associated with cardiovascular disease and atherosclerosis. High fasting insulin appears to be an independent predictor of ischaemic heart disease in middle aged and elderly men, after adjustments for other known risk factors (systolic blood pressure, family history, plasma triacylglycerols, apolipoprotein B, LDL and HDL cholesterol). Fasting insulin levels just 20\% above normal were associated with a 1.6 to 2 -fold higher risk of heart disease ${ }^{99,100}$. These results support the notion that hyperinsulinaemia increases the risk of heart disease through metabolic alterations other than dyslipidaemia.

The prevalence of each component of the metabolic syndrome varies among populations. The phenotypic expression of the underlying metabolic defects, namely IR and hyperinsulinaemia will be determined by the overall prevalence of the genetic defect in the population and the modulating factors such as age, weight, and physical fitness of the individual.

Central obesity, also termed abdominal obesity, is a powerful predictor of the metabolic syndrome. It is sometimes described as a 'Cushingoid' form of obesity because of the apparent similarities with Cushing's syndrome. In fact numerous studies have shown that obesity is characterised by an increased production of cortisol, combined with an elevated fractional turnover rate at the liver or kidney, which results in normal or lower than normal circulating cortisol levels. Although it seems clear that central obesity is more likely to be related to pathological cortisol secretion, this has not been fully studied $^{101}$. The metabolic functions of cortisol are related to its capacity to stimulate gluconeogenesis in the liver and reduce glucose utilisation in all cells. This combined effect will increase glycaemia in a great extent (>50\% normal values) such as to be called suprarenal diabetes. Another effect is to mobilise fat from adipose tissue, raising fatty acid levels in plasma thus contributing to IR.

Regardless of the cause of increased plasma FFA, the consequence will be significant perturbations in glucose and lipid metabolism. At the immediate site of generation FFA, that is at the endothelial cell surface, high FFA levels can inhibit LPL activity by interfering with cofactor apoCII/LPL activation or dislodge LPL from its endothelial cell anchorage in adipose tissue and muscle. The increased circulating FFA will increase production of apoB lipoproteins in the liver. The net result will be a rise in VLDL and LDL production and therefore greater risk for atherosclerosis. In addition, FFA stimulates hepatic glucose production and modulates gene expression of multiple enzymes such as fatty acid synthase, acetyl CoA carboxylase, malic enzyme, pyruvate kinase and PEPCK $^{102,103}$. FFAs also interfere with insulin clearance by the liver and stimulate secretion of other factors such as plasminogen activator inhibitor (PAI-I). Fatty acids' effects in the modulation of hepatic glucose production constitutes a hypothetical mechanism on how insulin exerts its inhibiting role on liver ${ }^{104}$.

In muscle, increased FFAs will interfere with normal glucose utilisation in several ways. An increased flux of fatty acids decreases muscle glycogen synthase and muscle glycogen stores, thereby reducing glucose oxidation. In some studies this effect is accompanied by a raised fat oxidation but this is still a matter of controversy ${ }^{105-107}$.

In the pancreas, FFA promotes insulin secretion and with chronic exposure it leads to beta cell apoptosis ${ }^{108}$. Within the arterial wall, fatty acids have been shown to promote the growth of smooth muscle and the activation of T-lymphocytes, both processes involved in the development of atherosclerosis.

Finally, in adipose tissue, FFA can directly increase glycerol-3-phosphate acyltransferase activity enhancing triacylglycerols storage, interfere with stimulated glucose transport, modify adipocyte membrane composition, gene regulation and adipocyte differentiation. These effects are mediated by PUFAs, arachidonic acid and fatty acid derivatives (prostaglandins and others) in direct interaction with PPAR $\gamma$ that appears to play a critical role in adipocyte differentiation and lipid storage. Fatty acids stimulate the secretion of angiotensin II and leptin by adipocyte. Dietary lipoproteins (chylomicrons) increase the production of acylation stimulating protein (ASP) from adipocyte, both in vitro and in vivo ${ }^{109-111}$.

In relation to hypertension, IR correlates directly with the severity of the hypertension. Comparisons of normotensive, untreated hypertensive and treated hypertensive patients shows higher plasma glucose, insulin levels and IR in both normotensive and hypertensive groups, indicating that blood pressure alone does not determine the abnormalities. Insulin mediated glucose uptake is reduced by $30-40 \%$ in people with essential hypertension ${ }^{112-114}$.

\section{Other consequences of energy excess and obesity}

Obesity is associated with the development of osteoarthritis and gout and, in obese middle-aged women at or after menopause, pain at the medial aspect of the knee (Adiposa Dolorosa Juxta-Articularis). The strength of the data supports mechanical damage above other causes. The increased risk of gout associated with obesity may be related to the accompanying hyperuricaemia although central fat distribution may also be involved, particularly in women ${ }^{115-117}$ 
Obesity impairs respiratory function and structure, leading to physiological and pathophysiological impairments. Sleep apnoea is the most serious of these and occurs in more than $10 \%$ of men and women with a BMI of 30 or above. BMI above 40 has been associated with sleep apnoea in $77 \%$ of cases. In addition to BMI, obstructive sleep apnoea is related to central obesity and to neck size, probably due to narrowing of the upper airway when recumbent ${ }^{118,119}$.

\section{Health consequences of excess weight gain in childbood and adolescence}

Obesity-related symptoms in children and adolescents include psycho-social problems, increased cardiovascular risk factors, abnormal glucose metabolism, hepaticgastrointestinal disturbances, sleep apnoea and relatively orthopaedic complications.

The most significant long-term consequence of excessive weight gain during childhood is to become obese during the same age period, persist throughout adolescence and into adulthood, along with all the associated health risks. The persistence of obesity is more likely when its onset is in late childhood or adolescence and when the obesity is severe ${ }^{120,121}$. Overweight in adolescence has also been shown to be significantly associated with longterm mortality and morbidity ${ }^{122}$. High BMI during adolescence has been related to an earlier onset of puberty by 0.6 years in boys and 0.7 year in girls. Each increased unit of BMI gain in childhood reduced the height gain in adolescence by $0.88 \mathrm{~cm}$ for boys and $0.51 \mathrm{~cm}$ for girls ${ }^{123}$.

\section{Psychosocial effects}

The most common consequence of obesity in children of Western societies is related to psychosocial functioning. Pre-adolescent children associate an overweight body shape (or silhouette) with poor social functioning, impaired academic success and reduced fitness and health $^{124}$. However, there is little evidence to suggest that self-esteem is significantly affected in obese young children $^{125}$.

On reaching the teenage years, however, crosssectional studies consistently show an inverse relationship between body weight and both overall self-esteem and body image, particularly among white females and Hispanics $^{126}$. Low self-esteem has long been regarded as a factor, which contributes to the development of fatness and is the central element of the psychosomatic theory of obesity in which food is associated with comfort. Adolescence is a period when a marked self-awareness of body shape and physical appearance develops. Therefore, it is perhaps not surprising that the pervasive, negative social messages associated with obesity in many communities have an impact at this stage. Overweight in adolescence may also be associated with later social and economic problems.
A large prospective study from the USA has shown that women who were overweight in late adolescence and early adulthood are more likely to have lower family incomes, higher rates of poverty and lower rates of marriage than women with other forms of chronic physical disability but who were not overweight in childhood.

Fear of fatness has become a common condition that affects both normal weight and overweight girls since the early age of 5 years old ${ }^{127}$. This feeling is associated with growth failure and delayed puberty in adolescent girls. Data from the Oxford Community study indicate that 40\% of bulimic adults had a history of childhood obesity in comparison to $15 \%$ in normal controls ${ }^{128}$.

\section{Cardiovascular and metabolic risk factors}

The rate of weight gain during childhood is a significant factor for adult cardiovascular risk. Findings from The Minneapolis Children's Blood Pressure Study found that weight gain during childhood is significantly related to young adult risk factors for cardiovascular disease ${ }^{129}$. Dyslipidaemia, hypertension and IR are frequently present in obese children, and dyslipidaemia appears to be related to increased abdominal fat distribution ${ }^{130-132}$.

As has been found in adults, NIDDM is rising with obesity during childhood. Equally, obesity and familial history of NIDDM are the most important risks factors. Pinhas-Hamiel et al. found that in the age group from 0 to 19 years old, it accounts for one third of all new cases of diabetes seen in some institutions in the USA ${ }^{133}$.

Serum lipid and lipoprotein levels, blood pressure and plasma insulin all follow from childhood into young adulthood with obesity at baseline being a significant predictor of adult values ${ }^{134,135}$.

\section{Other consequences of energy excess}

Hepatic complications in obese children have been reported; particularly hepatic steatosis, which is characterised by raised serum transaminase levels ${ }^{136}$. Abnormal liver enzymes may be associated with cholelithiasis but this condition is rare in children and adolescents.

Gastroesophageal reflux and gastric emptying disturbances which affect a minority of obese children may be a consequence of raised intra-abdominal pressure due to increased abdominal fat.

It is well documented that obese children can suffer from orthopaedic complications. The more serious of these include slipped capital femoral epiphyses ${ }^{137}$ and Blount's disease (a bone deformity resulting from overgrowth of the tibia) ${ }^{138,139}$ while the more minor abnormalities include knock knee (genu valgum) and increased susceptibility to ankle sprains.

Obstructive sleep apnoea is another complication of childhood and adult obesity ${ }^{140,141}$ which has been reported to cause hypoventilation and even sudden death in severe cases $^{142}$. Adults with morbid obesity $(\mathrm{BMI}>40)$ represent a growing segment of the obese 
population, particularly in the USA, this group is specially vulnerable to sleep apnoea. Sleep disturbances include changes in the amount of active sleep, which in turn modify metabolic response, food intake and physical activity. Recent studies indicate that sleep alterations may aggravate the metabolic consequences of obesity ${ }^{143}$.

\section{Perinatal risk associated to maternal energy imbalance}

Women of reproductive age in energy excess are at risk not only for hyperlipidaemia, hypertension, and diabetes mellitus, but also for infertility and for maternal and foetal complications during pregnancy, delivery, and the postpartum period. Overweight and obesity among pregnant women have become the most frequent highrisk obstetric condition in industrialised countries. A recent French study ${ }^{144}$ reported the cost of hospital prenatal care was five times higher in mothers who were overweight before pregnancy than in normal women. Progravid overweight increases maternal and foetal morbidity, the duration of hospitalisation for mothers was also higher. Infants requiring admission to a neonatal intensive care unit was approximately 3.5 times higher in cases of maternal obesity. Excess energy stores increases the risk of caesarean delivery and adverse infant outcomes. The rate of caesarean delivery was more than 60\% higher among obese women (BMI $>29 \mathrm{~kg} \mathrm{~m}^{-2}$ ) than among non-obese women after controlling for age, multiparity, high birth weight, and pregnancy complications ${ }^{145}$.

Independent of other risk factors, maternal obesity appears to increase the risk of delivering an infant with major congenital malformations - neural tube defects, in particular $^{146}$. Several studies ${ }^{147}$ have found that overweight women were $30-40 \%$ more likely than normal weight women to deliver an infant with a major congenital malformation. Recent case-control studies ${ }^{148-151}$ have confirmed these findings. However, potential biases in other factors affecting embryogenesis may confound the observed associations.

Infants born to women with a prepregnancy BMI of $30 \mathrm{~kg} \mathrm{~m}^{-2}$ or more are 2.0-4.2 times more likely to die in the perinatal period compared with infants born to women with a prepregnancy BMI less than $20 \mathrm{~kg} \mathrm{~m}^{-2}$. Infants born to women with a prepregnancy BMI of 25-30 are 1.5 times more likely to die in the perinatal period ${ }^{152}$. These associations remained after adjusting for measured covariates such as parity, diabetes status, the presence of hypertensive disorders, smoking, age, and socioeconomic status.

Energy excess evidence by a prepregnancy BMI $\left(>25 \mathrm{~kg} \mathrm{~m}^{-2}\right)$ and/or a weight gain of at least $5 \mathrm{~kg}$ in early adulthood are independent risk factors for gestational diabetes $^{153}$. Gestational diabetes mellitus affects 3-5\% of pregnancies and is associated with increased risk for perinatal morbidity ${ }^{154}$ and perinatal mortality. Overweight women with a prepregnancy BMI of $25-29.9 \mathrm{~kg} \mathrm{~m}^{-2}$ were
2.2 times more likely to develop gestational diabetes compared with women with a normal prepregnancy BMI. Obese women with a prepregnancy BMI of 30 or more were three times more likely to do so. Adjustment for age, family history of gestational diabetes, parity, ethnicity, and pregravid physical activity level did not change the association $^{153}$. The increased risk for gestational diabetes with greater weight gains was higher for non-white than for white women ${ }^{153}$. These findings suggest that avoiding the accumulation of fat in the early adult years is important to reduce the risk of gestational diabetes.

The risks of gestational hypertension and pre-eclampsia increase with increasing $\mathrm{BMI}^{155}$. Compared with women with a prepregnancy BMI of 21-22.9, women with a BMI of $25-29.9 \mathrm{~kg} \mathrm{~m}^{-2}$ were 1.7 times as likely to develop hypertension during pregnancy, and those with a prepregnancy $\mathrm{BMI}>29 \mathrm{~kg} \mathrm{~m}^{-2}$ were 2.1 times as likely to develop pre-eclampsia. Adjustment for confounders increased the RR for both associations ${ }^{155}$.

Obesity increases the relative risk of primary and secondary infertility by up to $70 \%{ }^{156,157}$. The most common cause of anovulatory infertility is polycystic ovary disease (PCOD). Losing weight decreases androgen concentrations and increases ovulation among obese women ${ }^{158-163}$. Although there are many causes of infertility, a healthy weight is associated with the highest fertility potential and best birth outcome.

In addition recent evidence from longitudinal observational population surveys indicate that after correcting for other intervening variables, overweight and obesity are associated with delayed onset of lactation and decreased duration of breastfeeding. Thus, obesity should be included amongst the risk factors for poor lactation performance ${ }^{164,165}$.

These findings reinforce the need to develop effective strategies to prevent energy excess early in life and throughout the reproductive cycle (pregnancy and lactation) to reduce the risk of becoming overweight and obese and to improve pregnancy outcomes.

\section{Transition from energy deficit to energy excess: potential effects of nutrition interventions}

\section{Early malnutrition and later energy excess}

Foetal growth retardation due to poor placental function, maternal malnutrition or other environmental factors can produce a baby with small size at birth. This condition has been associated with IR and increased risk for type II diabetes $^{166}$, impaired glucose tolerance ${ }^{166,167}$, and elevated serum insulin levels in adults ${ }^{167}$. A 'thrifty phenotype' hypothesis, proposed by Hales and Barker ${ }^{99}$, posits an effect of prenatal nutrition on foetal development that becomes evident in later life. Animal experiments support this hypothesis. When pregnant rats are fed an isocaloric, protein restricted diet, their offspring have lower birth weights, reduced islet vascularisation ${ }^{168}$ and impaired 
insulin response ${ }^{169}$. Some of the damage seems to be irreversible, provision of a normal diet after birth does not completely restore normal insulin response in adulthood $^{169}$. Furthermore, these first generation rats go on to have diabetic pregnancies, and their offspring exposed to hyperglycaemia in utero, are more likely to become diabetics adults ${ }^{170}$. Thus, an initial in utero insult induces endocrine dysfunction across two generations of rats. The tendency of type II diabetes to run through maternal line of human families ${ }^{171}$, and the higher incidence of NIDDM among children of women who had this disease while they were pregnant compared with those whose mothers developed type II diabetes after pregnancy ${ }^{172}$ support the influence of in utero environment in determining future risk for type II diabetes. Animal models show that maternal diet during pregnancy may permanently alter pancreatic endocrine function. Potential mechanisms include prenatal hormone and growth factors, particularly insulin-like growth factors 1 and its binding proteins ${ }^{173}$. The causal mechanisms underlying the association between birthweight and the risk for adult chronic disease remains obscure.

Significant relationships have been observed between indices of abnormal foetal growth and the development of a variety of adult diseases including essential hypertension, ischaemic heart disease, cerebrovascular disease, elevated plasma cortisol concentrations, NIDDM with metabolic syndrome X, ovarian hyperandrogenism, pronounced adrenarche, obstructive pulmonary disease and reduction in bone mineral densities.

Present trends in the prevalence of overweight and obesity in children seem to be raising in most developing countries. A recent survey of representative samples from 94 countries of the available information has shown that this is true but not for the majority of countries since undernutrition remains a major public health problem worldwide. Global prevalence of obesity (W/H $>2 \mathrm{SD}$, WHO standard) was 3.3\%. Within Latin America the prevalence was higher for South America reaching 4.9\% on average with Argentina, Chile, Bolivia, Peru and Costa Rica among the highest rates $(7.3,7.0,6.5,6.4$ and 6.2\%, respectively) ${ }^{174}$.

\section{Supplementary feeding programmes}

Supplementary feeding programmes are a fact of life for most developing countries. A recent FAO survey with data from 19 Latin American countries found that over 20\% of the population or approximately 83 million people out of an estimated 414 million in these countries receive some level of food assistance benefits from nutrition-related programmes ${ }^{175}$. In contrast, the number of malnourished in the study countries was 10 million, which is $12 \%$ of total beneficiaries. The explanation for this phenomenon is that nutrition programmes have evolved beyond the immediate needs of the malnourished and have become part of social economic benefit demanded by populations living under poverty. Despite the obvious benefits, namely the significant reductions in underweight and wasting which have occurred in most countries, these programmes have the potential to affect the trends in obesity rates. Also, stunting remains a problem in this region. In this setting providing food supplements may be beneficial for some while it may be detrimental for others. Careful selection of beneficiaries of food assistance programmes and determining the right combination of nutrients/foods, education, and lifestyle interventions that is required to optimise nutrition and health at each stage of the life cycle is a problem that cannot be avoided ${ }^{175}$.

Chile is a good example since it is often presented as a paradigm of the success of supplementary feeding programmes. Indeed, the association between the presence of these massive interventions and the decline in malnutrition in all age groups is evident. Unfortunately, these programmes may be also contributing to the rising prevalence in obesity. Specific examples will be given in an effort to show the impact that these assistance programmes may have on the prevalence in obesity and to signal the road ahead for other countries undergoing the rapid nutrition transition.

The Complementary Feeding Program (PNAC) is directed to approximately 1.2 million children under 6 years of age and 200000 pregnant women. This corresponds to approximately $80 \%$ of the national population of infants under 2 years and $70 \%$ of pre-school children, pregnant and nursing mothers. The programme supplies $100 \%$ of energy requirements in 5-month old infants and $30 \%$ in 2-6 year old children. Protein contribution is considerably higher with 180 and 58\% of protein requirements, respectively.

A separate example is drawn from the National Nursery Schools Council Program (JUNJI). It provides child care as well as supplementary food for toddlers and pre-schoolers; coverage is close to $50 \%$ of those in need. It also provides social assistance to the family when required. In 1998, approximately 100000 children under five attended JUNJI. Of those, 95\% were pre-schoolers from 2 to 5 years of age, and the rest, infants under 2 years old. The food distributed covers $58-75 \%$ of the children's daily estimated energy needs, depending on whether they attend for a half or a full day. The energy contribution is divided by age groups as follows: Under 12 months $800 \mathrm{Kcal}, 12-24$ months $950 \mathrm{Kcal}, 2-5$ years $1000 \mathrm{Kcal}$. If a nutritional deficit is detected, a reinforcement of $150 \mathrm{Kcalday}^{-1}$ is provided ${ }^{176}$. Analysis performed with the data obtained in the same children at the beginning and end of the year has found a rise in obesity prevalence $(>2 Z$-score $\mathrm{W} / \mathrm{H})$ during the period. The prevalence tended to be progressively higher with the age cohort.

A retrospective analysis done with 8086 children attending JUNJI's daycare centres over 3 years, allowed us to mimic a longitudinal follow up ${ }^{177}$. At the time of entry into the programme a total of 408 exceeded $+2 Z \mathrm{~W} / \mathrm{H}$ 
Table 3 Economic costs of obesity

\begin{tabular}{|c|c|c|c|c|c|}
\hline Country & Year & Study & $\begin{array}{l}\text { Obesity } \\
\text { definition }\end{array}$ & $\begin{array}{l}\text { Estimated } \\
\text { direct } \\
\text { costs }\end{array}$ & $\begin{array}{l}\% \text { National } \\
\text { health } \\
\text { care costs }\end{array}$ \\
\hline USA & 1990 & Wolf and Colditz ${ }^{a}$ & $\mathrm{BMI}>29$ & US\$ 45 billion & $6.8 \%$ \\
\hline Australia & $1989-90$ & $\mathrm{NHMRC}^{\mathrm{b}}$ & $\mathrm{BMI}>30$ & AUD\$ 464 million & $>2 \%$ \\
\hline Netherlands & $1981-89$ & Seidell \& Deerenberg ${ }^{C}$ & $\mathrm{BMI}>25$ & Guilders 1 billion & $4 \%$ \\
\hline France & 1992 & Levy et al. ${ }^{d}$ & $\mathrm{BMI}>27$ & FF 12 billion & $2 \%$ \\
\hline
\end{tabular}

Abbreviation: $\mathrm{BMI}$ - body mass index.

Source: Obesity, preventing and managing the global epidemic. WHO, 1998.

aWolf AM, Colditz GA. The costs of obesity: the US perspective. PharmacoEconomics 1994; 5: 34-37.

${ }^{b}$ National Health and Medical Research Council. Economic issues in the prevention and treatment of overweight

and obesity. In: Acting on Australia's weight: a strategic plan for the prevention of overweight and obesity. Canberra.

Australian Government Publ. Service. 1997:85-95.

${ }^{\mathrm{c}}$ Seidell J, Deerenberg I. Obesity in Europe - prevalence and consequences for the use of medical care.

PharmacoEconomics 1994; 5(suppl):38-44.

${ }^{\mathrm{d}}$ The economic cost of obesity: the French situation. Int J Obesity 1995; 19: 788-793.

while 3 years later 1211 exceeded that limit. That is a 3 -fold increase in the number of obese children over a 3-year period. During this same period, the number of overweight children (over $+1 \mathrm{Z}$ ) went from 1440 to 2160, that is a $50 \%$ increase. Given this situation, the programme has presently reduced energy supply by $100 \mathrm{kcal}$, saturated fat content of the ration has also been reduced, skimmed milk is being provided, additional fresh fruits and vegetables has been added, favouring the supply of calcium, micronutrients (iron and zinc) and fibre ${ }^{178}$.

In summary, nutrition intervention programmes, especially in stunted populations seem to be partially contributing to an obesity epidemic. Better focusing of beneficiaries, use of a combination of nutritional indices weight and height to detect stunted overweight children, and the qualitative improvement of food programmes, including sufficient micronutrient supply should be encouraged to prevent energy excess. Specific recommendations for infants and children are:

1. Monitor growth (weight and length/height) of infants and children with adequate standard (present standards are being revised based on growth of breastfed infants). Existing (WHO) norms may promote obesity since they were obtained from predominantly formula fed infants in rural Ohio, USA.

2. Exclusive breast feeding for the first 6 months of life not only provides energy for normal growth but may prevent obesity later on. Introduce complementary foods and supplements for infants at the right time, usually not before 6 months of age. If complementary foods are needed earlier consider the risks associated with interference with breast feeding and possible energy excess.

3. Prevent energy excess and obesity by avoiding overfeeding. Early prevention of obesity in later life should include no added sugar, starches or fat in formula unless required.

4. Identify infants and children at risk for energy deficit based on social and biological factors. Provide adequate care and food support for families at risk of malnutrition rather than for all individuals in a community.

5. Identify infants and children at risk for energy excess based on family background and lifestyle. Provide advice on healthy diet, prevention of energy excess and promote physical activity.

\section{Economic costs of excessive body weight}

\section{Burden of disease}

The economic cost and burden of diseases associated with, excess body weight has been assessed by few studies. Some of the data available from developed countries are summarised in Table 3. The scope and methodology of them vary considerably in terms of the diseases cost, the definition of obesity, the cost categories used and the epidemiological assumptions on the relationship between obesity and disease. This makes it difficult to compare costs across countries and to extrapolate the results from one country to another. The limited data available suggest that anywhere between $2 \%$ and $8 \%$ of total healthcare expenditure in a country may be directly attributable to obesity (Table 3).

In recent World Bank studies in Chile (World Bank Country Studies Series 1995), the burden of disease has been expressed in terms of disability adjusted life years (DALY) lost. NCDs account for a 5 and 9-fold greater rate of premature death than communicable diseases in men and women, respectively, and 10 and 5-fold greater rates of disability. The DALYs lost in men are 15-fold, and in women 20-fold, greater for NCD than for infections. So far, the burden of disease attributable to excess weight gain and obesity has not been calculated but cancers impose a substantial burden as do diabetes and cardiovascular diseases. Thus there is now a need to apply the new economic analyses of the proportion of those diseases attributable to excess weight gain so that the impact of one 
of the principal contributors to NCDs can be recognised in the developing world.

In less developed countries where NCD epidemics are emerging or accelerating, a large proportion of NCD deaths occur in the productive middle years of life, at ages much younger than witnessed in the developed countries. The health burdens attributable to excess weight in these transitional societies are likely to be huge, due to the absolute numbers at risk, the large loss in life expectancy and the fact that the problem affects, in particular, individuals with a key role in promoting economic development.

\section{Other economic effects}

A number of studies have used methods other than 'cost of illness' studies to describe the 'economic' impact of obesity related diseases. These studies have generally focused on the influence of obesity on either social class attainment, or on the impact on pension and disability payments.

It is important to note that indirect costs of disease relate to the loss of worker productivity (e.g. worker absenteeism, staff turnover and reduced worker productivity) as a result of obesity-related morbidity together with lost earnings due to premature death due to an obesity-related disease. A common misconception among health professionals is that sickness, unemployment and other social welfare benefits should be included as the indirect costs of diseases. Economists do not include these in cost-of-illness studies as they are viewed as a transfer payment from the tax paying population to the benefit recipient. There is further debate among health economists about whether to include indirect costs in a study and how to measure these costs reliably.

Although there have not been any comparable studies of the economic impact of obesity in developing countries, both the $\mathrm{WHO}^{179}$ and the World Bank ${ }^{180}$ have recently highlighted the escalating burden associated with the rapidly emerging adult NCDs in the developing world. These diseases now account for more deaths than infection. In developing countries, about $50 \%$ of deaths in 1990 were caused by NCDs, but by 2020, that proportion is expected to climb to almost $77 \%$. In 1990 , some $42 \%$ of deaths were attributed to infectious and reproductive conditions, while by 2020 , that proportion is expected to decline to about $12 \%$. In contrast, in developed countries $87 \%$ of deaths in 1990 were from NCDs and will only rise slightly to $90 \%$ by 2020.

\section{Research needs}

\section{Biological and genetic variability in energy requirement}

There is a need to evaluate whether genetic variability in energy requirements may determine distinct population subgroups with specific susceptibility to excess. The traditional nutritional model of dietary recommendations assumes a normal distribution and a homogenous population. For energy, the mean requirement becomes the recommendation in a non-homogeneous population.

\section{Foods}

Research is needed on the interactions of energy sources in foods within a meal not only in defining true energy utilisation, but also in determining its metabolic effects, particularly in terms of adipogenesis, IR and lipoprotein metabolism. The study of how energy excess and diet's macronutrient composition may affect various biological functions such as distribution, growth and secretion of adipose tissue, cardiovascular health, preservation of bone and muscle mass, host defence and immunity - may define new recommendations beyond the goal of normal weight.

The aim of modern nutrition in this case is not only avoiding obesity in terms of weight but also preserving long-term health. The diet being a modulator of gene expression must be used in the future to promote benefits and avoid consequences in the acute and the long-term.

Additional research is needed to define the energy value of foods as they are actually consumed and to learn how food consumption patterns and specific culinary preparations determine health benefits or risks. A science based on this is needed to redirect our dietary guidelines for the population.

\section{Social determinants}

The social and cultural determinants of food choices need to be better defined. The assumption that information is sufficient to modify behaviour has been proved wrong. Social research is needed on how to adjust food based dietary guidelines to achieve the goal of modifying consumer behaviour and lifestyle.

Consumer demand drives food production, and if we cannot influence the choice of healthy foods by consumers, little will be gained from establishing recommendations. Social marketing research approaches for the implementation of dietary recommendations should be evaluated, used and periodically redefined.

\section{Implications for policy}

The control and prevention of undernutrition due to insufficient food energy remains a major problem for many developing countries. At the same time energy excess and positive energy balance is a major determinant of nutritionrelated chronic diseases, presently the main cause of disability and death globally. Changes in diets, food culture and physical activity patterns during work and leisure are causing obesity and its consequences even in the poorest countries. A child that experiences malnutrition in early life, followed by inappropriate diets and physical inactivity in childhood and adult life, increases vulnerability to chronic diseases. Evidence from industrialised countries, as well as many developing countries, shows that nutrition-related 
chronic diseases prematurely disable and kill a large proportion of economically productive people; a preventable loss of precious human capital. Low-income communities are especially vulnerable to energy excess and obesity, which is not a disease of affluence. Current rates of overweight and obesity most of all in children, young adults and women, project rapidly increasing disability and premature death from nutrition-related chronic diseases for most developing countries. Phenomenal social and economic changes, on a scale and at a speed unprecedented in history, have resulted in an epidemic of nutrition-related chronic diseases that must be contained.

Prevention is the only feasible approach to obesity control. The cost of treatment and management imposes an intolerable economic burden on developing countries. There is an urgent need for governments, in partnership with all relevant constituencies, to integrate strategies to promote healthful diets and regular physical activity throughout life into all relevant policies and programmes including those designed to combat undernutrition. Obesity is preventable. This has already been demonstrated by successful programmes in a few developed countries. The chief causes are inappropriate diet and nutrition, and physical inactivity. Exposure to these factors is largely determined by political, economic and commercial policies and practices, which reflect decisions made at national and transnational levels. Effective programmes and policies will include not only health promotion and education but community empowerment and action to overcome the environmental, social, and economic constraints to improvement in dietary quality and reduction of sedentarism.

\section{References}

1 Schwartz MW, Baskin DG, Kaiyala KJ, Woods SC. Model for the regulation of energy balance by the central nervous system. American Journal of Clinical Nutrition 1999; 69: 584-96.

2 Horn CC, Addis A, Friedman MI. Neural substrate for an integrated metabolic control of feeding behavior. American Journal of Physiology 1999; 276: R113-9.

3 Drewnosky A. Macronutrient substitutes and weight reduction practices of obese, dieting and eating disordered women. Annals of the New York Academy of Sciences 1997; 819: $132-41$.

4 Green SM, Blundell JE. Subjective and objective indices of the satiation effects of foods. Can people predict how filling a food will be? European Journal of Clinical Nutrition 1996; 50: 798-806.

5 Grunwald G, Seagle H, Peters J, Hill J. Quantifying and separating the effects of macronutrient composition and non-macronutrients on energy density. British Journal of Nutrition 2001; 86: 265-76.

6 Blundell JE, Stubbs RJ. High and low carbohydrate and fat intakes: limits imposed by appetite and palatability and their implications for energy balance. European Journal of Clinical Nutrition 1999; 53(Suppl. 1): S148-65.

7 Stubbs RJ, Harbron CJ, Murgatroyd P, Prentice AM. Covert manipulations of dietary fat and energy density: effects on substrate flux and food intake in men eating ad libitum. American Journal of Clinical Nutrition 1995; 62: 316-29.

8 Stubbs RJ, O'Reilly LM, Johnstone AM, Reid CA. An experimental model to assess macronutrient selection in humans. International Journal of Obesity 1997; 21(Suppl. 2): $213-7$

9 O'Reilly LM, Stubbs RJ, Johnstone AM, Mara O, Robertson $\mathrm{K}$. Covert manipulation of the energy density of mixed diets on ad-libitum food intake in free-living humans. Proceedings of the Nutrition Society 1997; 56: 127.

10 Bell EA, Rolls BJ. Energy density of foods affects energy intake across multiple levels of fat content in lean and obese women. American Journal of Clinical Nutrition 2001; 73: 1010-8.

11 FAO Carbohydrates in human nutrition. Food and Agriculture Organization, Food and Nutrition Paper No. 66. Report of a Joint FAO/WHO Expert Consultation. Rome, 1998

12 Ritz P, Krempf M, Cloarec D, Charbonnel B. Compartive continuous indirect calorimetry study of two carbohydrates with different glycemic indices. American Journal of Clinical Nutrition 1991; 54: 855-9.

13 Blaak EE, Saris W. Postprandial thermogenesis and substrate utilization after ingestion of different dietary carbohydrates. Metabolism Clinical and Experimental 1996; 45: 1235-42.

14 Sparti A, Milon H, Di Vetta V, Schneller P, Tappy L, Jequier E, Schutz Y. Effects of diets high or low in unavailable and slowly digestible carbohydrates on the pattern of 24-h substarte oxidation and feelings of hunger in humans. American Journal of Clinical Nutrition 2000; 72: 1461-8.

15 McDevitt R, Poppitt S, Murgatroyd P, Prentice AM. Macronutrient disposal during controlled overfeeding with glucose, fructose, sucrose, or fat in lean and obese women. American Journal of Clinical Nutrition 2000; 72: 369-77.

16 Prentice AM. Alcohol and obesity. International Journal of Obesity 1995; 19(Suppl. 5): S44-S50.

17 Jebb S, Prentice AM, Goldberg G, Murgatroyd P, Black A, Coward WA. Changes in macronutrient balance during over- and underfeeding assessed by 12-d continuous whole body calorimetry. American Journal of Clinical Nutrition 1996; 64: 259-66.

18 Hellerstein MK. De novo lipogenesis in humans; metabolic and regulatory aspects. European Journal of Clinical Nutrition 1999; 53: S63-S65.

19 Acheson KJ, Scutz Y, Bessard T, Flatt JP, Jequier E. Carbohydrate metabolism and de novo lipogenesis in human obesity. American Journal of Clinical Nutrition 1987; 45: 78-85.

20 Ludwig D, Majzoub J, Al-Zahrani A, Dallal G, Blanco I, Roberts S. High glycemic index foods, overeating and obesity. Pediatrics 1999; 103: E261-6.

21 Booth DA, Chase A, Campbell AT. Relative efectiveness of protein in the late stages of appetite supression in man. Physiology and Behavior 1970; 5: 1299-302.

22 Wadden TA, Sunkard AJ, Day SC, Gould RA, Rubin CR. Less food, less hunger: reports of a protein-sparing modified fast. International Journal of Obesity 1987; 11: 239-49.

23 Hill Aj, Magson LD, Blundell JE. Hunger and palatability: tracking ratings of subjective experience before, during and after food consumption of preferred food. Appetite 1986; $\mathbf{5}$ : $361-71$.

24 Geliebter AA. Effects of equicaloric loads of protein, fat and carbohydrate on the food intake in the rat and man. Physiology and Behavior 1978; 22: 267-73.

25 de Graaf C, Hulshof T, Westsrate JA, Jas P. Short term effects of different amounts of protein, fats, and carbohydrates on satiety. American Journal of Clinical Nutrition 1992; 55 : $33-8$.

26 Sunkin S, Garrow J. The satiety value of protein. Human Nutrition Applied Nutrition 1982; 36: 197-201. 
27 Araya H, Hills J, Alviña M, Vera G. Short-term satiety in preschool children: a comparison between high protein meal and a high complex carbohydrate meal. International Journal of Food Sciences and Nutrition 2000; 51: 119-24.

28 Barkeling B, Rossner S, Bjorvell $\mathrm{H}$. Effects of a high protein meal (meat) and a high carbohydrate meal (vegetarian) on satiety measured by automated computerized monitoring of subsequent food intake, motivation to eat and food preferences. International Journal of Obesity 1990; 14: $743-51$

29 Saris W. Fit, fat and fat-free. International Journal of Obesity 1999; 22(Suppl. 2): S15-S21.

30 King NA, Tremblay A, Blundell JE. Effects of exercise on appetite control: implications for energy balance. Medicine and Science in Sports and Exercise 1997; 29: 1076-89.

31 King NA. The relationships between physical activity and food intake. Proceedings of the Nutrition Society 1998; 57: 77-84.

32 Albala C, Vio F. Epidemiological transition in Latin America: the case of Chile. Public Health 1995; 109: 431-42.

33 Popkin BM. Nutritional patterns and transition. Population and Development Reviews 1993a; 19: 138-57.

34 Ministry of Health. Performance report. Health care in Chile 1999. Department of management and control. Santiago: Ministry of Health, Communications and Public Relations, 1999.

35 Panamerican Health Organization (PAHO), World Health Organization (WHO). Core data. United Nations, World Population Prospects 1996. Revision, 1998. Special Program on health Analysis. PAHO. Available on line www.paho.org

36 National Institute of Statistics (INE). Demographic Annual Reports 1970 and 1998. Santiago: National Institute of Statistics.

37 Berrios X. Changing tendencies in the prevalence of risk factors for the chronic diseases: is a new epidemic coming? Revista Medica de Chile 1997; 125: 1405-7.

38 Berríos X, Jadue L, Zenteno J, Ross MI, Rodriguez H. Prevalence of risk factors for chronic diseases: a population study in the metropolitan area of Santiago Chile 19861987. Revista Medica de Chile 1990; 118: 597-604.

39 Berrios X. Risk factors in adult chronic diseases. An example of epidemiologic research. Boletin Esc. Medicina P. Universidad Catolica de Chile 1994; 23: 73-89.

40 Jadue L, Vega J, Escobar MC, Delgado I, Garrido C, Lastra P, Espejo F, Peruga A. Risk factors for chronic non communicable diseases: methods and results of CARMEN program basal survey. Revista Medica de Chile 1999; 127: 1004-13.

41 Vega J, Jadue L, Escobar MC, Jalil J, Espejo F, Delgado I, Garrido C, Lastra P, Peruga A. Prevalence of hypertension in Valparaíso: results of the base survey of CARMEN project. Revista Medica de Chile 1999; 127: 729-38.

42 Vio F, Albala C. Nutrition policy in the Chilean transition. Public Health Nutrition 2000; 3: 49-55.

43 Valenzuela A, Uauy R. Consumption pattern of dietary fats in Chile: n3 and n6 fatty acids. International Journal of Food Sciences and Nutrition 1999; 50: 127-33.

44 Albala C, Vio F, Kain J. Obesity: an unresolved challenge in Chile. Revista Medica de Chile 1998; 126: 1001-9.

45 Castillo C, Atalah E, Benavides M, Urteaga C. Patrones alimentarios en adultos que asisten a consultorio de atención primaria en la región Metropolitana. Revista Medica de Chile 1997; 125: 283-9.

46 Prentice AM. Fires of life: the struggles of an ancient metabolism in a modern world. Food and Nutrition Bulletin 2001; 26: 13-27.

47 Leyton J, Drury P, Crawford M. Differential oxidation of saturated and unsaturated fatty acids in vivo in the rat. British Journal of Nutrition 1987; 57: 383-93.

48 Raclot T, Groscolas R. Diferential mobilization of white adipose tissue fatty acids according to chain length, unsaturation, and positional isomerism. Journal of Lipid Research 1993; 34: 1515-26.

49 Connor W, Lin D, Colvis C. Differential mobilization of fatty acids from adipose tissue. Journal of Lipid Research 1996; 37: $290-8$.

50 DeLany J, Windhauser M, Champagne C, Bray G. Differential oxidation of individual dietary fatty acids in humans. American Journal of Clinical Nutrition 2000; 72 905-11.

51 Power G, Newsholme E. Dietary fatty acids influence the activity and metabolic control of mitochondrial carnitine palmitoyltransferase I in rat heart and skeletal muscle. Journal of Nutrition 1997; 127: 2142-50.

52 Kabir Y, Ide T. Activity of hepatic fatty acid oxidation enzymes in rats fed alpha-linolenic. Biochimica et Biophysica Acta 1996; 1304: 105-19.

53 Ide T, Murata M, Sugano M. Stimulation of the activities of hepatic fatty acid oxidation enzymes by dietary fat rich in alpha-linolenic acid in rats. Journal of Lipid Research 1996 37(3): 448-63

54 Forbes GB, Brown M, Welle S, Lipinsky B. Deliberate overfeeding in women and men: energy cost and composition of weight gain. British Journal of Nutrition 1986; 56: $1-9$.

55 Stock M. Gluttony and thermogenesis revisited. International Journal of Obesity 1999; 23: 1105-17.

56 Schutz Y. Human overfeeding experiments: potentials and limitations in obesity research. British Journal of Nutrition 2000; 84: 135-7

57 Jebb S, Murgatroyd P, Goldberg G, Prentice AM, Coward WA. In vivo measurements of changes in body composition: description of methods and their validation against 12-d continuous whole-body calorimetry. American Journal of Clinical Nutrition 1993; 58: 455-62.

58 Horton TJ, Drougas H, Brachey A, Reed GW, Peters JC, Hill JO. Fat and carbohydrate overfeeding in humans: different effects on energy storage. American Journal of Clinical Nutrition 1995; 62: 19-29.

59 Diaz E, Prentice AM, Goldberg, Murgatroyd P, Coward WA Metabolic response to experimental overfeeding in lean and overweight healthy volunteers. American Journal of Clinical Nutrition 1992; 56: 641-55.

60 Miller DS, Mumford P, Gluttony L. An experimental study of overeating on high protein diets. American Journal of Clinical Nutrition 1967; 20: 1212-22.

61 Allison DB, Kaprio J, Korkeila M, Koskenvuo M, Neale MC, Kayakawa K. The heritability of body mass index among an international sample of monocygotic twins reared apart. International Journal of Obesity 1996; 20: 501-6.

62 Krief S, Lonnqvist F, Raimbault S, Baude B, Van Spronsen A Arner P, Strosberg A, Rickier D, Emorine L. Tissue distribution of beta-3 adrenergic receptor mRNA in man. Journal of Clinical Investigation 1993; 91: 344-9.

63 Lohnnqvist F, Thorne A, Nilsell K, Hofftedt J, Arner P. A pathogenetic role of visceral fat beta-3 adrenoreceptors in obesity. Journal of Clinical Investigation 1995; 95: 1109-16.

64 Sakane N, Yoshida T, Umekawa T, Kondo M, Sakai Y, Takahashi T. Beta-3 adrenergic receptor polymorphism: a genetic marker for visceral fat obesity and the insulin resistance syndrome. Diabetologia 1997; 40: 200-4.

65 Clement K, Ruiz J, Cassard-Doulcier A. Additive effect of the UCP protein gene and the Trp64Arg mutation of the beta-3-adrenergic receptor gene on weight gain in morbid obesity. International Journal of Obesity 1996; 20: 1062-6.

66 Large V, Hellstrom L, Reynisdottir S, Lonnqvist F, Ericksson P, Lannfelt L, Arner P. Human beta-2 adrenoceptor gene polimorphisms adrenoceptor function. Journal of Clinical Investigation 1997; 100: 3005-13.

67 Oberkofler H, Esterbauer H, Hell E, Krempler F, Patsch W The Gln27Glu polymorphism in the beta-2 adrenergic 
receptor gene is not associated with morbid obesity in Austrian women. International Journal of Obesity 2000; 24: 388-90.

68 Meirhaeghe A, Hebecque N, Cottel D, Amouyel P. Beta-2 adrenoceptor gene poimorphism, body weight and physical activity. Lancet 1999; 353: 896.

69 Rosmond R, Ukkola O, Chagnon M, Bouchard C, Bjorntorp P. Polymorphisms of the beta-2 adrenergic receptor gene in relation to cardiovascular risk factors in men. Journal of Internal Medicine 2000; 248: 239-44.

70 Klannemark M, Orho M, Groop L. No relationship between variants in the UCP2 gene and energy expenditure. European Journal of Endocrinology European Federation of Endocrine Societies 1998; 139: 217-21.

71 Chung M, Luke A, Cooper R. Genetic and physiologic analysis of the role of UCP3 in human energy homeostasis. Diabetes 1999; 48: 1890-5.

72 Greens I. Activation of a member of the steroid hormone receptor superfamily by peroxisome proliferators. Nature 1990; 347: 1070-6.

73 Schoonjans K, Staels B, Auwerx J. Role of the peroxisome proliferator-activated receptor (PPAR) in mediating the effects of fibrates and fatty acids on gene expression. Journal of Lipid Research 1996; 37: 907-25.

74 Shalev A, Siegrist-Kaiser C, Yen P, Wahli W, Burger A, Chin $\mathrm{W}$, Meier $\mathrm{C}$. The peroxisome proliferator-activated receptor a is a phosphoprotein: regulation by insulin. Endocrinology 1996; 137: 4499-505.

75 Vidal-Puig A, Considine R, Jimenez-Liñan M, Werman A, Pories W, Caro J, Flier J. Peroxisome proliferator-activated receptor gene expression in human tissues. Journal of Clinical Investigation 1997; 99: 2416-22.

76 Ristow M, Muller-Wieland D, Pfeiffer A, Krone W, Kahn R. Obesity associated with a mutation in a genetic regulator of adipocyte differentiation. New England Journal of Medicine 1998; 339: 953-9.

77 Moller DE, Flier JS. Insulin resistance: mechanisms, syndromes, and implications. New England Journal of Medicine 1991; 325: 938-48.

78 Moitra J, Mason MM, Olive M, Krylov D, Gavrilova O, Marcus B, Feigenbaum L, Lee E, Aoyama T, Eckhaus M, Reitmann ML, Vinson C. Life without fat: a transgenic mouse. Genes and Development 1998; 12: 3168-81.

79 Martin G, Schoonjans K, Staels B, Auwerx J. PPAR- $\gamma$ activators improve glucose homeostasis by stimulating fatty acid uptake in the adipocytes. Atherosclerosis 1998; 137: 75-80.

80 Wu Z, Xie Y, Morrison RF, Bucher NL, Farmer SR. PPAR- $\gamma$ induces the insulin dependent glucose transporter GLUT- 4 in abscence of $\mathrm{C} / \mathrm{EBP} \alpha$ during the conversion of 3T3 fibroblast into adipocytes. Journal of Clinical Investigation 1998; 101: 22-32.

81 Rocchi S, Auwerx J. Peroxisome proliferator activated receptor- $\gamma$, the ultimate liaison between fat and transcription. British Journal of Nutrition 2000; 84(Suppl. 2): S223-7.

82 Deeb S, Fajas L, Nemoto M, Laakso M, Fujimoto W, Auwerx $\mathrm{J}$. A Pro12Ala substitution in the human peroxisome PPAR$\gamma 2$ is associated with decreased receptor activity, improved insulin sensitivity, and lowered body mass index. Nature Genetics 1998; 20: 284-7.

83 Yen CJ, Beamer BA, Negri C, Silver K, Brown KA, Yarnall DP, Burns DK, Roth J, Shuldiner AR. Mollecular scanning of the human PPAR gamma gene in diabetics caucasians; identification of a Pro12Ala PPAR gamma 2 missense mutation. Biochemical and Biophysical Research Communications 1997; 241: 270-4.

84 Beamer BA, Yen CJ, Andersen, et al. Association of the Pro12Ala variant in PPAR gamma 2 gene with obesity in two Caucasian populations. Diabetes 1998; 47: 1806-8.
85 Mori Y, Kim-Motoyama H, Katakura T, Yasuda K, Kadowaki H, Beamer BA, Shuldiner AR, Akanuma Y, Yazaki Y, Kadowaki T. Effect of the Pro12Ala variant of the human PPAR gamma 2 on adiposity, fat distribution and insulin sensitivity in Japanese men. Biochemical and Biophysical Research Communications 1998; 251: 195-8.

86 Ek J, Urhammer SA, Sorensen TI, Andersen T, Auwerx J, Pedersen O. Homozygosity of the Pro12Ala variant of PPAR gamma 2: divergent modulating effects on body mass index in obese and lean men of Caucasian origin. Diabetologia 1999; 42: 892-5.

87 Reaven GM. Role of insulin resistance in human disease. Diabetes 1988; 37: 1595-607.

88 Rosenblum A, Joe JR, Young RS, Winter WE. Emerging epidemic of type II diabetes in youth. Diabetes Care 1999; 22: $345-54$.

89 Stumvoll M, Jacob S. Multiple sites of insulin resistance: muscle, liver and adipose tissue. Experimental and Clinical Endocrinology and Diabetes: Official Journal, German Society of Endocrinology and German Diabetes Association 1999; 107: 107-10.

90 Storlien L, Pan D, Kriketos A, Connor J, Caterson I, Cooney G, Jenkins AB, Baur LA. Skeletal muscle membrane lipids and insulin resistance. Lipids 1996; 31: S261-5.

91 Pan D, Lillioja S, Milner M, Kriketos A, Baur L, Bogardus C, Storlien LH. Skeletal muscle membrane lipid composition is related to adiposity and insulin action. Journal of Clinical Investigation 1995; 96: 2802-8.

92 Shulman GI. Cellular mechanisms of insulin resistance. Journal of Clinical Investigation 2000; 106(2): 171-6.

93 Hotamisligil G, Shargill N, Spiegelman B. Adipose expression of Tumor Necrosis Factor- $\alpha$ : direct role in obesity-linked insulin resistance. Science 1993; 259: 87-93.

94 Saghizadeh M, Ong J, Garvey T, Henry R, Kern P. The expression of TNF- $\alpha$ by human muscle. Journal of Clinical Investigation 1996; 97: 1111-6.

95 Ferrannini E, Natali A, Bell P, Cavallo-Perin P, Lalic N, Mingrone G. Insulin resistance and hypersecretion in obesity. Journal of Clinical Investigation 1997; 100: 1166-73 on behalf of the European Group for the Study of Insulin Resistance (EGIR).

96 Lillioja S, Mott DM, Howard BV, Bennett PH, Yki-Jarvinen H, Freymond D, Nyomba BL, Zurlo F, Swinburn B, Bogardus C. Impaired glucose tolerance as a disorder of insulin action. Longitudinal and cross-sectional studies in Pima indians. New England Journal of Medicine 1988; 318: 1217-25.

97 Granner DK, O'Brien RM. Molecular physiology and genetics of NIDDM. Diabetes Care 1992; 15: 369-95.

98 Hales CN, Barker DJ. Type 2 (non-insulin dependent) diabetes mellitus: the thrifty phenotype hypothesis. Diabetologia 1992; 35: 595-601

99 Depres JP, Mauriege P, Cantin B, Dagenais GR, Moorjani S, Lupien PJ. Hyperinsulinemia as an independent risk factor for ischemic heart disease. New England Journal of Medicine 1996; 334: 952-7.

100 Feskens EJM, Kromhout D. Hyperinsulinemia, risk factors and coronary heart disease. The Zuphen elderly study. Arteriosclerosis and Thrombosis: a Journal of Vascular Biology American Heart Association 1994; 14: 1641-7.

101 Bjorntorp P, Rosmond R. The metabolic syndrome - a neuroendocrine disorder? British Journal of Nutrition 2000; 83(Suppl. 1): S49-S57.

102 Sessler AM, Ntambi JM. Polyunsaturated fatty acid regulation of gene expression. Journal of Nutrition 1998; 128: 923-6.

103 Cheema SK, Clandinin MT. Diet fat alters expression of genes for enzymes of lipogenesis in lean and obese mice. Biochimica et Biophysica Acta 1996; 1299: 284-8.

104 Bergman R, Mittelman S. Central role of the adipocyte in insulin resistance. Journal of Basic and Clinical Physiology and Pharmacology 1998; 9(2-4): 205-21. 
105 McGarry JD. Glucose fatty acid interactions in health and disease. American Journal of Clinical Nutrition 1998; 67: $5500-4$

106 Colberg SR, Simoneau JA, Thaete FL, Kelley DE. Skeletal muscle utilization of free fatty acid in women with viscera obesity. Journal of Clinical Investigation 1995; 95: 1846-53.

107 Van Baak MA, Schiffelers SLH, Saris WHM. Increased NEFA availability leads to a similar increase in energy expenditure and fat oxidation inlean and obese men. International Journal of Obesity 1998; 22: S157.

108 Shimabukuro M, Zhou YT, Levi M, Unger RH. Fatty acidinduced beta cell apoptosis: a link between obesity and diabetes. Proceedings of the National Academy of Sciences of the United States of America 1998; 95: 2498-502.

109 Maslowska M, Scantebury T, Germinario R, Cianflone K. Acute in vitro production of ASP in differentiated adipocytes. Journal of Lipid Research 1997; 38: 21-31.

110 Scantlebury T, Maslowska M, Cianflone K. Chylomicron specific enhancement of acylation stimulating protein (ASP) and precursor protein C3 production in differentiated human adipocytes. Journal of Biological Chemistry 1998; 273: 20903-9.

111 Saleh J, Summers LKM, Cianflone K, Fielding BA, Sniderman AD, Frayn KN. Coordinated release of acylation stimulating protein (ASP) and triacylglicerol clearance by human adipose tissue in vivo in the postprandial period. Journal of Lipid Research 1998; 39: 884-91.

112 Ferrannini E, Buzzigoli G, Giorico MA, Oleggini M, Graziadei L, Pedrinelli R, Brandi L, Bevilacqua S. Insulin resistance in essential hypertension. New England Journal of Medicine 1987; 317: 350-7.

113 Reaven GM. Relationship between insulin resistance and hypertension. Diabetes Care 1991; 14: 33-8.

114 De Fronzo RA, Ferranini E. Insulin resistance: a multifaceted syndrome responsible for NIDDM, obesity, hypertension, dyslipidemia and atheroesclerotic cardiovascular disease. Diabetes Care 1991; 14: 173-94.

115 Davis MA, Neuhaus JM, Ettinger WH, Mueller WH. Body fat distribution and osteoarthritis. American Journal of Epidemiology 1990; 132: 701-7.

116 Roubenoff R, Klag MJ, Mead LA, Liang KY, Seidler AJ, Hochberg MC. Incidence and risk factors for gout in white men. Journal of the American Medical Association 1991; 266: 3004-7.

117 Felson DT, Zhang Y, Anthony JM, Naimark A, Anderson JJ. Weight loss reduces the risk for symptomatic knee osteoarthritis in women. The Framingham study. Annals of Internal Medicine 1992; 116: 535-9.

118 Vgontzas AN, Tan TL, Bixler EO, Martin LF, Shubert D, Kales K. Sleep apnea and sleep disruption in obese patients. Archives of Internal Medicine 1994; 154: 1705-11.

119 Strollo PJ, Rogers RM. Current concepts: obstructive sleep apnea. New England Journal of Medicine 1996; 334: 99-104.

120 Abraham A, Collins G, Nordsieck M. Relationship of childhood weight status to morbidity in adults. HSMHA Health Reports 1971; 86: 73 .

121 Guo SS, Roche AF, Chumlea WC, Gardner JD, Siervogel RM. The predictive value of childhood body mass index values for overweight at age $35 \mathrm{y}$. American Journal of Clinical Nutrition 1994; 59: 810-19.

122 Must A, Jacques PF, Dallal GE, Bajema CJ, Dietz WH. Longterm morbidity and mortality of overweight adolescents. New England Journal of Medicine 1992; 327: 1350-5.

123 Qing H, Karlberg J. BMI in childhood and its association with height gain, timing of puberty, and final height. Pediatric Research 2001; 49: 244-51.

124 Hill AJ, Silver EK. Fat, friendless and unhealthy: 9 year old children's perception of body shape stereotypes. International Journal of Obesity 1995; 19: 423-30.
125 Klesges RC, Haddock CK, Stein RJ, Klesges LM, Eck LH, Hanson CL. Relationship between psychosocial functioning and body fat in preschool children: a longitudinal investigation. Journal of Consulting and Clinical Psychology 1992; 60: 793-6.

126 Strauss R. Childhood obesity and self-esteem. Pediatrics 2000; 105: 1-5.

127 Feldman W, Feldman E, Goodman JT. Culture versus biology: children's attitudes toward fatness and thinness. Pediatrics 1988; 81: 190-4

128 Fairburn CG, Cooper Z. New perspectives on dietary and behavioral treatment for obesity. International Journal of Obesity 1996; 20(Suppl.): S9-S13.

129 Sinaiko A, Donahue R, Jacbos D, Prineas R. Relation of weight and rate of increase in weight during childhood and adolescence to body size, blood pressure, fasting insulin, and lipids in young adults. The Minneapolis children's blood pressure study. Circulation 1999; 99: 1471-6.

130 Lauer RM, Connor WE, Leaverton PE, Reiter MA, Clarke WR. Coronary heart disease risk factors in school children: The Muscatine study. Journal of Pediatrics 1975; 86: 697-706.

131 Steinberger J, Morehead C, Katch V, Rocchini AP. Relationship between insulin resistance and abnormal lipid profile in obese adolescents. Journal of Pediatrics 1995; 126: 690-5.

132 Brambilla P, Manzoni P, Sironi S, Simone P, Del Maschio A, di Natale B, Chiumello G. Peripheral and abdominal adiposity in childhood obesity. International Journal of Obesity 1994; 18: 795-800.

133 Pinhas-Hamiel O, Dolan L, Daniels S, Standiford D, Khoury $\mathrm{P}$, Zeitler P. Increased incidence of non-insulin dependent diabetes mellitus among adolescents. Journal of Pediatrics 1996; 128: 608-15.

134 Bao W, Strinivasan SR, Wattigney WA, Berenson GS. Persistence of multiple cardiovascular risk clustering related to syndrome $\mathrm{X}$ from childhood to young adulthood. The Bogalusa heart study. Archives of Internal Medicine 1994; 154: 1842-7.

135 Raitakari OT, Porkka KV, Rasanen L, Ronnemaa T, Viikari JS. Clustering and six year cluster-tracking of serum total cholesterol, HDL-cholesterol and diastolic blood pressure in children and young adults. The cardiovascular risk in young Finns study. Journal of Clinical Epidemiology 1994; 47: $1085-93$

136 Noguchi H, Tazawa Y, Nishinomiya F, Takada G. The relationship between serum transaminase activities and fatty liver in children with simple obesity. Acta Paediatrica Japonica 1995; 37: 621-5.

137 Loder RT. The demographics of slipped capital femoral epiphysis. An international multicenter study. Clinical Orthopaedics and Related Research 1996; 322: 8-27.

138 Dietz WH, Gross WL, Kirkpatrick JA. Blount disease (tibia vara): another skeletal disorder associated with childhood obesity. Journal of Pediatrics 1982; 101: 735-7.

139 Henderson RC, Greene WB. Etiology of late-onset tibia vara: is varus alignment a prerequisite? Journal of Pediatric Orthopedics 1994; 14: 143-6.

140 Silvestri JM, Weese-Mayer DE, Bass MT, Kenny AS, Hauptman SA, Pearsall SM. Polysomnography in obese children with a history of sleep-associated breathing disorders. Pediatric Pulmonology 1993; 16: 124-9.

141 Young T, Peppard P. Sleep disordered breathing and cardiovascular disease: epidemiologic evidence for a relationship. Sleep 2000; 23: S122-6.

142 Riley DJ, Santiago TV, Edelman NH. Complications of obesity-hypoventilation syndrome in childhood. American Journal of Diseases in Childhood 1976; 130: 671-4.

143 Spiegel K, Leproult R, Van Cauter E. Impact on sleep debt on endocrine and metabolic function. Lancet 1999; 354 $1435-9$. 
144 Galtier-Dereure F, Boegner C, Bringer J. Obesity and pregnancy: complications and cost. American Journal of Clinical Nutrition 2000; 71(Suppl.): S1242-S8.

145 Crane SS, Wojtowycz, Dye TD, Aubry RH, Artal R. Association between prepregnancy obesity and the risk of cesarean delivery. Obstetrics and Gynecology 1997; 89: 213-6.

146 Cogswell ME, Perry GS, Schieve LA, Dietz WH. Obesity in Women of Childbearing Age: Risks, Prevention, and Treatment. Submitted for publication in Primary Care Update for $O B / G Y N S, 2000$

147 Kallen K. Maternal smoking, body mass index, and neural tube defects. American Journal of Epidemiology 1998; 147: 1103-11.

148 Shaw GM, Velie EM, Schaffer D. Risk of neural tube defect affected pregnancies among obese women. Journal of the American Medical Association 1996; 275: 1093-6.

149 Waller D, Mills JL, Simpson JL, Cunningham GC, Conley MR, Lassman MR, Rhoads GG. Are obese women at higher risk for producing malformed offspring? American Journal of Obstetrics and Gynecology 1994; 170: 54-8.

150 Watkins M, Scanlon K, Mulinare J, Khoury M. Is Maternal obesity a risk factor for anencephaly and spina bifida? American Journal of Epidemiology 1994; 139: S11.

151 Werler MM, Louik C, Shapiro S, Mitchell AA. Pre-pregnant weight in relation to risk of neural tube defects. Journal of the American Medical Association 1996; 275: 1089-92.

152 Cnattinguis S, Bergstrom R, Lipworth L, Kramer S. Prepregnancy weight and the risk of adverse pregnancy outcomes. New England Journal of Medicine 1998; 338 : $147-52$.

153 Solomon CG, Wilett WC, Carey VJ, Rich-Edwards J, Hunter DJ, Colditz GA, Stampfer MJ, Speizer FE, Spiegelman D, Manson JE. A prospective study of pregravid determinants of gestational diabetes mellitus. JAMA Journal of the American Medical Association 1997; 278: 1078-83.

154 Magee MS, Walden CE, Benedetti TJ, Knopp RH. Influence of diagnostic criteria on the incidence of gestational diabetes and perinatal morbidity. JAMA Journal of the American Medical Association 1992; 269: 609-15.

155 Thadhani R, Stampfer MJ, Hunter DJ, Manson JE, Solomon CG, Curhan GC. High body mass index and hypercholesterolemia: risk of hypertensive disorders of pregnancy. Obstetrics and Gynecology 1999; 94: 543-50.

156 Rich-Edwards JW, Goldman MB, Willett WC, Hunter DJ, Stampfer MJ, Colditz GA. Adolescent body mass index and infertility caused by ovulatory disorder. American Journal of Obstetrics and Gynecology 1994; 171: 171-7.

157 Balen AH, Conway GS, Kaltsas G, Techatrasak K, Manning PJ, West C, Jacobs HS. Polycystic ovary syndrome: the spectrum of the disorder in 1741 patients. Human Reproduction 1995; 10: 2107-11.

158 Bates GW, Whitworth NS. Effect of body weight reduction of plasma androgens in obese, infertile women. Fertility and Sterility 1982; 38: 406-9.

159 Clark AM, Ledger W, Galletly C, Tomlinson T, Blaney F, Wang X, Norman RJ. Weight loss results in significant improvement in pregnancy and ovulation rates in anovulatory obese women. Human Reproduction 1995; 10: $2705-12$.

160 Harlass FE, Pylmate SR, Fariss BL, Belts RP. Weight loss is associated with correction of gonadotrophin and sex steroid abnormalities in the obese annovulatory female. Fertility and Sterility 1984; 42: 649-52.

161 Hollmann M, Runnebaum B, Gerhard I. Effects of weight loss on the hormonal profile in obese, infertile women. Human Reproduction 1996; 11: 1884-91.

162 Kiddy DS, Hamilton-Fairley D, Seppala M, Koistinem R, Jones VH, Reed MJ, Franks S. Diet-Induced changes in sex hormone binding globulin and free testosterone in women with normal or polycstic overies: Correlation with serum, insulin and insulin-like growth factor-1. Clinical Endocrinology 1989; 31: 757-63.

163 Kiddy DS, Hamilton-Fairley D, Bush A, Short F, Anyaoku V, Reed MJ, Franks S. Improvement in endocrine and ovarian function during dietary treatment of obese women with polycystic ovary syndrome. Clinical Endocrinology 1992; 36: $105-11$.

164 Chapman DJ, Perez-Escamilla R. Identification of risk factors for delayed onset of lactation. Journal of the American Dietetic Association 1999; 99: 450-4.

165 Donath SM, Amir LH. Does maternal obesity adversely affect breastfeeding initiation and duration? Breastfeeding Review Professional Publication of the Nursing Mothers' Association of Australia 2000; 8: 29-33.

166 Hales CN, Barker DJ, Clark PM, Cox LJ, Fall C, Osmond C, Winter PD. Fetal and infant growth and impaired glucose tolerance at age 64. British Medical Journal 1991; 303: 1019-22.

167 Robinson S, Walton RJ, Clark PM, Barker DJ, Hales CN, Osmond C. The relation of fetal growth to plasma glucose in young men. Diabetologia 1992; 35: 444-6.

168 Snoeck A, Remacle C, Reussens B, Hoet JJ. Effect of a low protein diet during pregnancy on the fetal rat endocrine pancreas. Biology of the Neonate 1990; 57: 107-8.

169 Dahri S, Snoeck A, Reussens-Billen B, Remacle C, Hoett JJ. Islet function in offspring of mothers on low-protein diet during gestation. Diabetes 1991; 40(Suppl. 2): 115-20.

170 Dahri S, Reussens B, Remacle C, Hoett JJ. Nutrirional influences on pancreatic development and potential links with non-insulin dependent diabetes. Proceedings of the Nutrition Society 1995; 54: 345-56.

171 Mitchell BD, Valdez R, Hazuda HP, Haffner SM, Monterrosa A, Stren MP. Differences in the prevalence of diabetes and impaired glucose tolerance according to maternal or paternal history of diabetes. Diabetes Care 1993; 16: 1262-7.

172 Pettitt DJ, Baird HR, Carraher MJ, Bennett PH, Knowler WC. Congenital susceptibility to NIDDM. Role of intrauterine environment. Diabetes 1988; 37: 622-8.

173 Langford K, Blum W, Nicolaides K, Jones J, Mc Gregor A, Miell J. The pathophysiology of the insulin like growth axis in fetal growth failure: a basis for programming by undernutrition? European Journal of Clinical Investigation 1994; 24(12): 851-6.

174 De Onis M, Blossner M. Prevalence of overweight among preschool children in developing countries. American Journal of Clinical Nutrition 2000; 72: 1032-9.

175 Uauy R, Mize C, Castillo-Durán C. Fat intake during childhood: metabolic responses and effects on growth. American Journal of Clinical Nutrition 2000; 72(Suppl.): S1354-S60.

176 Kain J, Pizarro F. Effect of an enhanced supplementary feeding program on infant's length. Archivos Latinoamericanos de Nutricion 1997; 47: 101-4.

177 Uauy R, Riumallo J. Work plan in support of guidelines on formulating and implementing nutrition programs (FINP) at the country level. Case Study: Chile. FAO, Rome 1997.

178 Rojas J, Uauy R. Need to prevent obesity without neglecting the protection of children at risk of malnutrition. Revista Chilena de Nutricion: Organo Oficial de la Sociedad Chilena de Nutricion Bromatologia y Toxicologia 1999; 26: 35-9.

179 The World Health Report. Conquering Suffering, Enriching Humanity. Geneva: WHO, 1997.

180 Murray CJ, Lopez AD, ed. The Global Burden of Disease. Boston: Harvard University Press, 1996. 